\title{
DIOSAS Y LEONES EN EL PERIODO ORIENTALIZANTE DE LA PENÍNSULA IBÉRICA
}

\section{GODESSES AND LIONS IN THE ORIENTALIZING PERIOD OF THE IBERIAN PENINSULA}

\author{
por \\ MARÍA BELÉN \\ María CRUZ Marín CEBallos ${ }^{1}$
}

\begin{abstract}
RESUMEN Numerosos documentos arqueológicos dejan entrever una estrecha relación entre divinidades femeninas y leones en las religiones del Próximo Oriente. Durante el I milenio a.C. Astarté se asimila con la mayor parte de las diosas cananeas anteriores, así como con las egipcias Hathor y Sekhmet. La variada y confusa iconografía que se atribuye revela los múltiples aspectos de su compleja personalidad. En la figura del león se encarna su naturaleza irascible y guerrera, de ahí que se muestre a veces con imagen felina. Durante el Período Orientalizante identificamos el rostro y los atributos simbólicos de la diosa sobre soportes muy diferentes. Como "Señora de los leones" se muestra en el jarro de Valdegamas y como leona de ferocidad comedida en el vaso del Museo Lázaro Galdiano, posiblemente. Abundantes paralelos apoyan esta hipótesis que constituye el aspecto más novedoso de este trabajo.
\end{abstract}

ABSTRACT number of archaeological documents let us glimpse a narrow relationship between feminine
divinities and lions in Near East religions. During the first millennium B.C., Astarte becomes
assimilated to most previous Canaan goddesses, as well as to the Egyptian Hathor and Sekhmet.
The assorted and confusing iconography that we attribute to her shows the many aspects of
her complex personality. The lion figure embodies her warlike and irascible nature, therefore
she is sometimes shown as a feline image. During the orientalizing period the goddess' face
and attributes are represented on very different ways. She is shown as Lady of the Lions on
the Valdegamas jug, possibly as a lioness of moderate fierceness on the vessel at Lazaro Galdiano
Museum. Many parallels support this hypothesis which is the most powerful aspect of this paper.

Palabras claves Religión fenicia. Iconografía. Diosas. Leones. Astarté. Orientalizante. Jarros metálicos.

Key words Phoenician religion. Iconography. Goddess. Lions. Astarte. Orientalizing. Metallic jugs.

1. Este trabajo ha sido realizado como actividad del grupo de investigación Religio Antiqua (HUM-650) de la Consejería de Educación de la Junta de Andalucía. Agradecemos la colaboración de Silvia Welsh. 
Uno de los temas recurrentes de la iconografía religiosa del antiguo Oriente Próximo es el que relaciona a una diośa, generalmente innominada, con el león. Dicha relación se establece de distintos modos y en diferentes ámbitos, aunque el más destacado y a la vez más importante para nuestros fines es el sirio-palestino. Como premisa imprescindible para valorar los posibles testimonios de ese tema en la Península Ibérica intentaremos resumir brevemente el estado de la cuestión en la región levantina del Mediterráneo.

\section{LA DIOSA Y EL LEÓN EN EL PRÓXIMO ORIENTE Y SU EXPANSIÓN EN EL MEDITERRÁNEO}

En primer lugar examinaremos los testimonios escritos de una diosa que recibe el apelativo de "la Leona". Entre los más significativos, un nombre teóforo documentado en la inscripción que aparece sobre cinco puntas de flecha procedentes de el-Khadr, al noroeste de Belén, en Palestina, datables entre los siglos XII-XI a.C.: $h s ̣$ ' $b d l b$ ' $t$, "flecha de 'Abdlabi'at", nombre interpretado como "siervo de la Leona"'. En un quinto ejemplar, tras el nombre aparece el epíteto bn ' $n t$, "hijo de Anat"' (Röllig 1995: 350). Este teóforo se ha querido ver también en Ugarit como nombre de un arquero (KTU 4.63 III 38) ${ }^{3}$. Como topónimo, aparece en Jos. 15:32 y 19:6: (byt) l'bwt. La identidad de esta diosa continúa, sin embargo, constituyendo un problema, aunque la referencia a Anat resulta muy sugestiva, como bien recuerda Ribichini (1995, 25), por diversas razones, aunque siempre desde la perspectiva que de ella nos ofrecen los textos de Ugarit: de un lado su relación con el arco y las flechas, patente en el mito de Aqhat, de otro su carácter violento y belicoso, acorde con la agresividad característica del león. Sin embargo, encontramos el epíteto Labbadu ya en los textos de Ebla del III milenio a. de C., en opinión de Pomponio y Xella (1997: 249) típico y exclusivo de AshtarIshtar. Se destaca también que el mismo epíteto: ${ }^{\mathrm{d} L a b a t u}$ se aplica a la diosa Ishtar en textos litúrgicos y léxicos cuneiformes (Puech 1999: 524-5;Lipinski 1999: 213-220). A manera de ejemplo puede verse una mención de Ishtar como leona en el llamado Poema de Agusaya, VIII, 24, de la época de Hammurabi de Babilonia, o en el relato de la victoria de Inanna sobre el Ebih, I, 9, de comienzos del II milenio, textos ambos en los que significativamente se exalta el aspecto guerrero y violento de la diosa (Bottéro y Kramer 1989: 214 y 219 respectivamente) $)^{4}$. S. Ribichini (1995: 25) se inclina en último término por esta posibilidad como antecedente para el teóforo citado, "senza que questo pregiudichi successivi accostamenti nella religione fenicia e punica tra il felino e altre figure divine femminili, in altre epoche e situazioni culturali". Ha de tenerse muy en cuenta, en todo caso, la estrecha relación que une a la acadia Ishtar con la Ashtar semita occidental (Ebla, Emar), sin que se pueda precisar, a la luz de la documentación actual, la derivación de ésta con respecto de aquélla (Bonnet 1996: 138). De otro lado, conviene tener presente la estrecha relación que en los textos de Ugarit, e incluso en las referencias egipcias, se da entre Anat y Ashtart como diosas cazadoras y belicosas (Wyatt 1984: 327-330).

El otro gran filón documental viene representado por las fuentes arqueológicas, más concretamente iconográficas. Sería difícil precisar el momento en que por primera vez hallamos al león asociado a la iconografía de una diosa que puede ser Inanna-Ishtar, o alguna otra con ellas relacionada, en el ámbito mesopotámico. Todo parece indicar sin embargo que la época acadia marca un hito en la manera de imaginar a los dioses y en la atribución a éstos de determinados símbolos, lo que es especialmente patente en los cilindros sellos (Limet 1985: 101). Desde ese momento, Ishtar se sitúa sobre un león, lo que se interpreta como expresión de su aspecto fiero, guerrero y, a la vez, victorioso (Limet 1985: 108; Black y Green 1992:

2. Inscripciones II, III, IV, X y XI del catálogo de Bordreuil 1982: 187-90.

3. Estos y otros datos han llevado a algunos autores a suponer la posible existencia de un cuerpo de arqueros en el ejército bajo la protección de Anat o Athirat, suponiendo que una de estas dos diosas fuese la "Leona", lo que ha sido muy discutido. Véase un estado de la cuestión en Ribichini 1995: 24-25. Recientemente, Puech 2000.

4. Véase en castellano Bottéro 2001: 58. 
118-119). Suele mostrarse vestida con el típico atavío de volantes y apoyando su pierna derecha sobre el lomo de un león (Black y Green 1992: 108, fig. 87) (Fig. 1), forma de la que sin duda deriva la imagen de la diosa de la célebre pintura mural del palacio de Zimri-Lim en Mari, del s. XVIII a. de C. (Parrot 1969: fig. 346). Otro esquema iconográfico que a menudo se le atribuye es el que la representa desnuda, alada a veces, y sobre uno o dos leones, como ocurre con el llamado relieve Burney, de comienzos del II milenio (Parrot 1969: fig. 367).

Pero es en la región siro-palestina y ya a partir del Bronce Tardío donde encontramos con mayor frecuencia a una diosa desnuda colocada generalmente en posición frontal, sobre un león ${ }^{5}$. Así sucede, por ejemplo, en Palestina, en Ugarit y las ciudades fenicias, así como en las conocidas como estelas de Qudshu en el Egipto del Imperio Nuevo. Los problemas de identificación que presentan estas imágenes, documentadas en distintos soportes y rodeadas de detalles que las diferencian entre sí, son numerosos y han dado lugar a una prolija bibliografía. En Palestina, la diosa se muestra con ramas en las manos, con o sin el león bajo sus pies, en placas de terracota procedentes de Lakish ${ }^{6}$. Sin duda relacionadas con estas figuraciones están las llamadas "placas de Astarté", en las que suele aparecer una figura femenina desnuda en posición frontal, sujetándose o no los senos, señalando el pubis con una mano, o con los brazos sencillamente a lo largo del cuerpo, sin ningún tipo de atributos (Keel-Uehlinger 1998: 110-122, figs. 121a-125). A veces, y en otro tipo de objetos, sin duda alguna relacionados con el culto, figuras similares se muestran enmarcadas en una pequeña capilla, templete o naiskos, y en otros casos ellas mismas, en este caso duplicadas, realizan la función de pilastras o columnas que lo flanquean. Así ocurre en un soporte cultual hallado hace unos años en Pella (Jordania), datable en el tránsito del Hierro I al IIA en el que las dos figuras femeninas desnudas, con los brazos pegados al cuerpo, se sitúan sobre cabezas de félidos (Keel y Uehlinger 1998: 116, fig. 126), lo que claramente emparenta estas imágenes con la diosa del león o el tipo Qudshu. La conclusión a que llegan estos autores es que la dificultad de atribución a una divinidad concreta, en este caso propia del ámbito palestino, no debe ocultarnos la realidad de un culto de gran arraigo popular a una deidad próxima a las necesidades de sus adoradoras, que tienen que ver con las circunstancias biológicas de la vida femenina. No se la puede identificar con ninguna en concreto: Ashera, Anat o Astarté, pero, añaden, más importante que el nombre de la diosa, que puede haber variado según la época y región, es la función de estas imágenes: en ellas se subraya la desnudez, juventud y atracción erótica (Ídem: 118-119). Durante la Edad del Hierro I, sin embargo, esta diosa del león parece haber perdido importancia en el ámbito palestino, y las esporádicas representaciones que de ella se conservan durante el Hierro II A parecen deberse a la influencia fenicia y nordsiria, donde estas imágenes mantienen un fuerte arraigo desde el Bronce Tardío y a lo largo de la Edad del Hierro (Ídem: 160).

Como antes apuntábamos, también en Ugarit y el Norte de Siria se documenta la diosa en relación con el león. En los cilindros sellos ugaríticos, a pesar de su esquematismo, encontramos a una figura femenina que se posa sobre un felino ${ }^{7}$. De Ugarit proceden igualmente una serie de colgantes de oro donde se la representa desnuda en varias formas que combinan el león bajo sus pies con otros atributos como los antílopes que cuelgan de sus manos, las flores de loto o papiro y las serpientes (Fig. 3$)^{8}$.

5. El origen de este esquema iconográfico se atribuye generalmente al ámbito anatólico-hitita.

6. Keel y Uehlinger (1998: 74-75, fig. 69-70) la interpretan como la versión egiptizante (por las flores de loto o papiro) de la antigua "diosa-rama" del Bronce Medio palestino.

7. Véase Amiet 1995: 71-72, $\mathrm{n}^{\circ} \mathrm{s}$. 149, 150 del catálogo. Recordemos también un conocido sello de esta misma procedencia en el que H. Gese (1970:159, fig. 16) ha visto a Anat, sentada sobre un toro y con casco de cuernos, y a Ashtart, desnuda y apoyada sobre dos leones unidos por sus cuartos traseros y con las cabezas vueltas (RS 5089=AO 17242).

8. Imágenes semejantes se documentan también en cilindros sellos de Siria y Chipre desde el Bronce Medio (Cornelius 1993: 32 , lám. IX figs. 23 y 24). 
Los pendientes de Ugarit nos introducen en la compleja problemática de Qudshu, que, aunque de forma sintética debemos abordar aquí, ya que afecta a nuestro tema. Todos ellos, pero muy especialmente AO 14.714 (fig. 3), reflejan de forma muy directa la iconografía de la diosa que vemos en un grupo muy concreto de estelas halladas en Egipto, generalmente conocidas como de Qdš o Qudshu (Edwards 1955: 49-51; Leibovitch 1961: 23-34; Helck 1971:217-222). La citada diosa presenta unos rasgos que ya nos son conocidos: desnuda, posa sus pies sobre un león pasante, y sostiene en sus manos flores y serpientes. A su lado derecho, el dios itifálico egipcio Min, al izquierdo, el sirio Reshep, con lanza y signo ankh. En las dedicatorias aparece su nombre: $Q d s ̌ o ~ Q d \check{s} t$. La casi totalidad se datan en las dinastías XVIII-XIX atribuyéndose a obreros de origen sirio que trabajan en la ciudad de Tebas (Deir el-Medina). Una de ellas, conservada en el Winchester College de Oxford (Edwards 1955: 49-51) presenta una triple inscripción jeroglífica: Qudshu-Anat-Ashtart (Fig. 2). La mayor parte de los autores se inclinan a pensar en una identificación entre estas tres diosas ${ }^{9}$ que estarían así representadas en la imagen de Qudshu sobre el león (Edwards 1955; Leibovitch 1961: 28-29), pero realmente se desconoce el alcance y significado real de la inscripción y su relación con la imagen allí representada, salvo en el caso del rótulo Qudshu, claro está. El problema, sin embargo, está en saber si éste es un nombre divino (Cornelius 1993: 30-31; Merlo 1997: 50) o un simple epíteto o hipóstasis ${ }^{10}$.

Un factor importante a tener en cuenta es la relación que se establece entre la diosa oriental y la Sekhmet egipcia. G. Garbini (1979: 327) ha sugerido una influencia egipcia justamente en el apelativo $l b$ ' $t$, "leona", que más arriba hemos estudiado. Aunque dicha posibilidad no puede negarse (Marín 1998: 2 y passim), ha de tenerse en cuenta la presencia de ese epíteto en Ebla ya durante el III milenio, así como otra documentación del área mesopotámica más arriba citada. En todo caso, parece bastante lógica una aproximación entre la diosa egipcia y la Ishtar-Ashtar del Próximo Oriente, al menos desde comienzos del II milenio, ya que en el Egipto del Reino Medio Sekhmet, la diosa de Menfis, esposa de Ptah, adquiere rasgos guerreros a la par que consolida su relación con el Sol y con la ideología de la realeza (Scandone 1993: 12-13). Esa relación se va haciendo más estrecha con el tiempo coincidiendo con el Imperio Nuevo egipcio y la conquista del área siro-palestina. La condición de "ojo del sol" de Sekhmet la convierte en protectora del rey en sus batallas, pero a la vez tiene un carácter maternal, siempre en relación con la figura del rey, que la aproxima a Mut y a Hathor (Marín 1995: 832-833). Todos estos rasgos la emparentan con la Ishtar-Ashtar próximo oriental, pero además ha de tenerse en cuenta la introducción de Ashtart en el panteón egipcio a partir de la dinastía XVIII, siguiendo diversas vías, entre las cuales está la "oficial", junto con Anat, en torno al dogma de la realeza, y la de los comerciantes fenicios instalados en el puerto de Menfis (Helck 1971:456-458). Sabemos que allí, y dentro del santuario de Ptah, existió un templo de Astarté, donde la diosa se mostraba como esposa-hija del dios patrón de la ciudad, constituyendo ésta una nueva vía de aproximación a Sekhmet, la esposa egipcia del dios ( $L \ddot{A} g$, IV, 1982: 28-33; Stadelmann 1967: 96-111). La identificación entre ambas diosas no deja sin embargo constancia iconográfica clara en Egipto hasta época muy tardía. Así, en el templo de Horus en Edfú, de la época de Ptolomeo XVI ${ }^{11}$, la encontramos con la cabeza leonina y vestida a la egipcia, montada sobre el carro real, entre las escenas del ciclo de la victoria de Horus. La inscripción al lado nos garantiza que se trata de Astarté: "Su majestad Re avanza, estando Astarté con él" (Fig. 4).

A la inversa, se puede constatar también una presencia de Sekhmet-Bastet en el ámbito siro-palestino, ya durante el Bronce Tardío, sobre todo en forma de amuletos que atestiguan el atractivo que la magia egipcia ejerció sobre las poblaciones del área, especialmente de Palestina (Hölb 1986: 11-53; Herrmann 1994:

9. La identificación de Qudshu con Ashera parece haberse descartado (Wiggins 1991: 386-389; Cornelius 1993: 29-33; Merlo 1994: 48-51).

10. Véase el análisis de Wyatt (1984: 336-337), quien habla de una posible "sincrasia" entre ellas, derivada de su papel en el dogma de la realeza.

11. Leclant 1960: 54-58. También se representa a Astarté con cabeza de leona en Kom Ombo (C.de Wit, Le rôle et le sens du lion dans l'Égypt ancienne, Bruselas 1951: 368). 
146-196). Pero es sobre todo a comienzos del primer milenio, con el advenimiento de las dinastías libias, originarias de Bubastis, patria de Bastet, cuando en Egipto se produce la mayor difusión del culto a esta diosa que se muestra idéntica a Sekhmet, ofreciendo el lado amable de aquella (Scandone 1993: 14-19). Esa "ola" alcanzó también al área siro-palestina, lo que se aprecia en diversas formas. Recientemente E. Gubel (2000: 197-198) ha destacado la frecuente representación de égidas de Sekhmet-Bastet en marfiles, cuencos, sellos y amuletos, dentro del área estudiada, planteando la hipótesis de un conocimiento directo por parte de "asiáticos" que habrían colaborado en la construcción por Osorkon II del templo de Bastet en Bubastis. ${ }^{12}$

Como era de esperar, Occidente se hace eco también del auge de este culto, y la imagen de Sekhmet-Bastet aparece en los yacimientos fenicio-púnicos del Mediterráneo central y occidental sobre diversos objetos. Uno de los más típicos son los conocidos como "estuches porta-amuletos" en oro, plata u otros metales que, rematando con una cabeza de leona, se documentan en Cerdeña, Sicilia, Cartago, Ibiza y, como se verá más adelante, en la Península Ibérica, datables entre los siglos VI al III a.C. (Quillard 1970-71:21-25; 1987: 92-95, láms. I y XXVIII). Pero también en forma de amuletos en piedra, fayenza o esteatita (Hölb 1986: 80 y 108-109; Redissi 1990: 163-216), siendo de destacar un magnífico ejemplar en piedra procedente de Cagliari (Fig. 5). Por último, y como veremos más detenidamente, no falta su imagen en escarabeos, e incluso en las páteras metálicas. ${ }^{13}$

Volviendo a "la diosa" semita occidental que se relaciona de un modo u otro con el león, la dificultad de atribuirle un nombre es menor durante la Edad del Hierro. Ello se debe básicamente al hecho de que la documentación escrita, mucho más restringida durante la misma a causa de la desaparición de las tablillas como soporte gráfico, y por tanto de la escritura cuneiforme, testimonia la ausencia de la mayor parte de estas diosas que hemos visto activas durante el II milenio. Problema aparte lo constituye el caso de Palestina, donde a través del Antiguo Testamento tenemos constancia de la pervivencia, al menos por unos siglos, de la diosa Ashera, trasunto de la Athirat ugarítica (Merlo 1998). Por lo que al área nordsiria y líbano-fenicia se refiere, la vieja Ashtar documentada en la zona desde el III milenio y que los textos ugaríticos llaman Attart, convertida en la Ashtart o Astarté fenicia, parece haber absorbido en un fenómeno sincretístico sin precedentes a la mayoría de las diosas conocidas durante el II milenio.

Sin embargo, la iconografía que relaciona a la diosa con el león, sí que pervive a lo largo del I milenio, extendiéndose además por el Mediterráneo con los colonos fenicios, pero, lógicamente, cambian los soportes y los esquemas iconográficos, a la vez que los conceptos que se esconden tras ellos. Lejos de pretender ser exhaustivos en la catalogación de estos testimonios, mostraremos no obstante algunos ejemplos significativos. En primer lugar citaremos una pequeña placa de terracota procedente de la necrópolis sidonia de Helaieh, conservada en el Louvre ${ }^{14}$, donde podemos ver un típico naiskos o capilla en cuyo interior, muy torpemente representada, una divinidad femenina desnuda posa sus pies sobre dos leones (Gubel 1986: 274-276, n. 39, fig. 10). La tenemos representada también sobre marfiles de Nimrud, como en la pieza, un frontal de arnés de caballo, en que se muestra desnuda, asiendo flores de loto con ambas manos, y flanqueada por dos cápridos. Sobre su cabeza el disco solar alado, mientras se sostiene sobre lo que parece ser una cabeza de leona sobre una palmeta (Gubel 1985: 195, fig. 9). Otro elemento de atavío de caballo, esta vez en bronce, procedente de Mileto, desgraciadamente muy fragmentario, nos muestra a tres diosas desnudas, mientras que en otra pieza sin duda relacionada con ésta, aparecen tres leones (Gubel 1985: 196, fig. 10). Citaremos también dos placas de oro, una en el Louvre, de origen desconocido ${ }^{15}$ que representa el busto de la diosa

12. Es interesante también constatar la presencia de Bastet en la onomástica fenicia de época helenística (Lemaire 1986: 88).

13. Por ejemplo en la pátera de bronce hallada en Francavilla Maritima, Calabria (Markoe 1984: 232, Ca1, 161-162).

14. AO 1471. dimensiones: $8^{\prime} 4 \times 4^{\prime} 9 \times 2^{\prime} 6 \mathrm{~cm}$.

15. AM 941, long. $8^{\prime} 9 \mathrm{~cm}$, ancho $4^{\prime} 9 \mathrm{~cm}$ (Karageorghis 1974: 31-35). 
desnuda sobre una cabeza de león (Gubel 1985: fig. 7), y otra muy semejante, del mercado de antigüedades libanés (Ídem, fig. 8). Por último, las dos piezas de bronce, del arnés de los caballos, hallados en la tumba $\mathrm{n}^{\circ} 79$ de Salamis, datable a fines del s. VIII, y atribuidas a una cierta influencia asiria sobre la isla: una representa a la diosa desnuda y alada sobre leones, sosteniendo a su vez otros dos con sus manos; en la otra vemos diversos registros en los que se mezclan tres diosas desnudas, flores de loto y de nuevo tres leones (Karageorghis 1969: 76-98). Se constata así de manera clara la conexión de esta diosa con los caballos, entendidos como arma bélica, lo que nos conduce a la figura de Ashtart en Egipto, uno de cuyos rasgos característicos, bien documentado en los textos, es su conexión con el carro de guerra del faraón (Gubel 1985: 192-202; Leclant 1960). Obsérvese también la frecuente triplicación de la diosa.

Como ya venimos diciendo hace años, y ha sido constatado recientemente por otros autores (Keel y Uehlinger 1998: 10-12), los escarabeos constituyen un fecundo campo de estudio para el conocimiento de la iconografía religiosa fenicia y, en este caso, de los fenómenos de identificación o acercamiento entre diversas diosas del ámbito mediterráneo. Queremos a este respecto traer a colación varias piezas que ilustran muy claramente cuanto se ha observado acerca de la deidad fenicia, muy probablemente Astarté, y el león, así como su relación con la egipcia Sekhmet. En primer lugar varios ejemplares procedentes de Tharros, catalogados por G. Hölb (1986). Así el no 166 (motivo XVIII.1, vol. I, p. 311), que muestra a tres divinidades femeninas con cabeza leonina, representadas de frente (Fig. 6). Llevan la parte superior del cuerpo desnuda, y con respecto a la inferior, las dos de los lados llevan una estrecha falda reticulada, que no es sino representación de las alas plegadas, envolviéndole el cuerpo, mientras que la del centro presenta estas alas abiertas hacia abajo, sobre una falda con decoración en espiga. Todas se tocan con las mechas hathóricas y el disco solar sobre la cabeza. Sobre la escena, el disco solar alado, debajo, el signo egipcio del cielo. Sin ninguna duda es la misma divinidad que encontramos en otro escarabeo (Ídem: $\mathrm{n}^{\circ} 167$, p. 312, motivo XVIII, 2), donde la diosa se muestra desnuda, con cabeza leonina, alas desplegadas, flores de loto en las manos y a ambos lados, y disco solar sobre su cabeza (Fig.7). Creemos que en esta imagen se expresa de modo patente el fenómeno sincrético producido entre ambas diosas, pues está claro que la desnudez, las flores de loto, incluso las alas, así como la posición frontal, son rasgos típicos de la deidad fenicia, con toda probabilidad en estos momentos Astarté, mientras que la cabeza leonina y el disco solar son propios de Sekhmet. Esta iconografía, por otra parte, se aproxima extraordinariamente a la del frontal de arnés procedente de Nimrud más arriba estudiado ${ }^{16}$. También de Tharros procede la pieza catalogada por Hölb (1986: 289) con el número 78, datada en el s. IV. Aquí la diosa leontocéfala se muestra de pie, con la típica falda de alas que se representa convencionalmente con un reticulado, tocada con el disco solar flanqueado de uraei, en la actitud de amamantar a un supuesto Horus niño, representado igualmente de pie (Fig. 8). Tras la cabeza de la diosa puede verse un hacha fenestrada, arma propia de determinadas deidades del área fenicia, con connotaciones que, en este caso, por la identificación con Sekhmet, creemos claramente bélicas ${ }^{17}$, sin por ello olvidar los atributós de diosa nutricia que son aquí quizá los más destacados, y que corresponden igualmente a esta diosa. Se ha de citar aquí también el ejemplar procedente de Ibiza en el que una diosa, vestida con larga túnica y tocada con un disco solar, apoya sus pies sobre un león y deja asomar a su espalda un hacha que, aunque torpemente representada, es sin duda la misma que se ha descrito en la pieza anterior, mientras que sostiene una lanza con la mano izquierda. Ante ella, un thymiaterion (Boardman 1984: $\mathrm{n}^{\circ}$ 60,44 , lám. XI).

16. Se han de mencionar igualmente los números 168 (Ídem,313), también de Tharros, con una diosa leontocéfala, tocada con la doble corona egipcia y entronizada ante un thymiaterion, sin duda Astarté-Sekhmet con una tipología ya propiamente fenicia, y 169 (Ídem, 313), donde la diosa de cabeza leonina se muestra arrodillada sobre una barca y coronada por disco solar y corona atef.

17. E. Gubel (1980: 1-17), a propósito de un escarabeo del Museum für Kunst und Gewerbe de Hamburgo, que representa a una diosa entronizada con hacha fenestrada, planteó, junto con esta posibilidad, la de interpretar este arma como un símbolo de poder y fertilidad, propio de dioses celestes. 
A algunos de los más significativos testimonios que relacionan a la diosa con el león producidos en el ámbito cartaginés ha dedicado una de nosotras un trabajo en fecha reciente (Marín 1995), lo que nos exime de tener que detallar ciertos datos. No obstante, la nueva perspectiva aquí adoptada nos va a permitir contemplar los resultados de aquel trabajo a la luz de un conocimiento más profundo del tema desde sus orígenes orientales. Es obvio que la imagen de Sekhmet es bien conocida en Cartago desde época arcaica, como se constata en los amuletos catalogados recientemente por T. Redissi (1990, passim), aunque también en escarabeos (Vercoutter 1945: $\mathrm{n}^{\text {os }} .65-69,110-111$ ), colgantes en forma de capilla, estuches porta-amuletos y bandas mágicas en ellos contenidos (Quillard 1970-71; Redissi 1990: 191-194), pero lo interesante para el propósito que ahora nos ocupa es observar la reinterpretación que allí se produce del tema de la diosa leontocéfala para dar lugar a una nueva personalidad divina, o mejor dicho, para dar forma iconográfica a una concepción de divinidad que, enraizada en los viejos cultos de la metrópolis tiria, va adquiriendo caracteres nuevos a la luz de las circunstancias históricas de la nueva ciudad, así como de las corrientes helenizantes que ahora dominan en el Mediterráneo. Nos estamos refiriendo, claro está, a la enigmática figura de Tanit o Tinnit. De gran significación de cara al testimonio iconográfico de esta reinterpretación es el estuche porta-amuletos de oro hallado en la tumba $\mathrm{n}^{\circ} 210$ de la necrópolis de Kerkouanne, datable entre los siglos V y IV (Redissi 1990: 192-193), en el que la diosa leontocéfala se muestra de cuerpo entero, sobre un pequeño podium, vestida con falda de alas y grandes hojas de hiedra en las manos. En la misma línea están las esculturas de terracota halladas por Merlin en el santuario de Thinissut, cerca de Siagu (Merlin 1910: 7-8, 16-17, 44-47, lám, III 1-2), que se han datado a comienzos de la era cristiana (Fig. 9). Un poco anterior a éstas es el denario acuñado en África por $Q$. Caecilius Metellus Pius Scipio, fechable entre el 48-46 a. C. (Sydenham 1952: $\mathrm{n}^{\circ} 1050$ ), con la misma diosa leontocéfala con falda de alas, y sobre ella el rótulo G.T.A., interpretado como Genius Terrae Africae, muy probablemente relacionado con el daimon Karchedonion del tratado entre Anibal y Filipo de Macedonia (215 a. de C.) que nos ha sido transmitido por Polibio (VII, 9, 2-3) (Marín 1995: 837-839). Lo interesante de esta nueva deidad leontocéfala, tan vieja en sus orígenes, es que ahora se convierte en símbolo "parlante" de la nueva provincia romana de África. Y así observamos cómo la Iuno Caelestis cartaginesa, heredera romana de la antigua Tanit, se representa

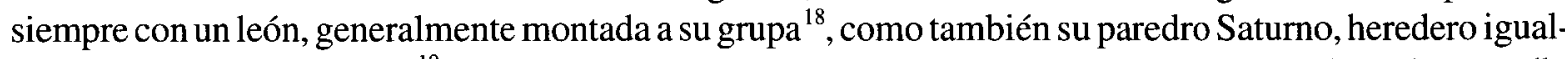
mente de los viejos Baales ${ }^{19}$ ya como montura, flanqueando su trono o simplemente echado junto a él.

\section{LA DIOSA Y EL LEÓN EN LA PENÍNSULA IBÉRICA}

Los testimonios que nos ofrece del tema la arqueología peninsular son pocos y de cronología dispar. El más antiguo es el cilindro sello de Vélez- Málaga, hoy en paradero desconocido (García Alfonso 1998) ${ }^{20}$. Su hallazgo se produjo antes de 1874 , al parecer en una tumba descubierta casualmente cerca de la citada ciudad y conocida sólo a través de los dibujos de Rodríguez de Berlanga (Fig: 10). La pieza se fecha entre 1450-1350 a. C. y acabó como elemento de un collar formado por cuentas de pasta vítrea, igualmente perdido (cf. Martín de la Cruz 1994! 119). Tallado en hematites, representa una escena en la que la diosa desnuda, con tallos terminados en flores de loto en ambas manos, tocada con una especie de casquete, esquematización del cabello, se posa sobre un león, o mejor leona, sobre la que aparecen unos glóbulos que probablemente evocan su carácter celeste. El resto de la temática representada nos muestra también a un daimon leontocéfalo u oficiante enmascarado, ya presente en otros sellos nordsirios y chipriotas, participando junto con otro

18. Así en el relieve del Museo Capitolino (Guarducci 1946-8: 21-24).

19. Se ha de tener presente que también los dioses masculinos se muestran a veces sobre un león en Oriente (Cornelius 1989: 63).

20. Seguimos al autor en el análisis de esta pieza, pero omitimos las referencias, salvo en citas textuales, para evitar reiteraciones. 
ser humano en un acto que quizá evoque el sacrificio de aves y cápridos en honor de la diosa. Para García Alfonso (1998: 63) "el cilindro-sello de Vélez-Málaga puede ser producto de algún taller activo a mediados del Bronce Reciente y situado en la costa siria, en su traspaís inmediato o incluso en la isla de Chipre. Todo apunta a que es obra de un artesano hurrita, que aquí trabajó al gusto de un cliente del litoral mediterráneo, aunque se concedió ciertas libertades". Para el autor la pieza debió depositarse como ajuar en una tumba de sillares como las de la necrópolis Jardín en fechas comprendidas en los siglos VI-V a.C.

En el mismo ámbito púnico encontramos representaciones de divinidades leontocéfalas en los prótomos animales de algunos colgantes porta-amuletos. Se consideran imágenes de Sekhmet (cf. Nicolini 1990: 399 y nota 78), cuya figura aparece también, junto con el nombre Horus de Psamético I, en un escarabeo hallado en la tumba $n^{\circ} 48$ de Alcacer do Sal (Gamer 1978: 104-105, fig. 30, lám. 28 a-b). El único ejemplar seguro (Gamer 1978: 74, lám. 20 a; Quillard 1987: 94-95, fig. 6 y lám. XXVIII; Nicolini 1990: 398-399 $\mathrm{n}^{\circ} 167$ ) procede, con otros dos, uno con cabeza de carnero y otro de halcón, de una tumba descubierta en 1891 en la zona de Punta de Vaca, en Cádiz. El prótomo, de leona más que león (Quillard 1987: 95; Nicolini 1990: 399; cf. Leclant 1960: 55, nota 3), está coronado por un disco con un uraeus (Fig. 11). La pieza, que combina oro con bronce, se considera de taller local y se fecha a comienzos del siglo IV a.C. Más antiguos (siglo V) son los dos ejemplares de la necrópolis de Puente de Noy, pero su deficiente estado de conservación impide asegurar si el animal es león o halcón (Padró 1995: 127-128 (nºs 24.57 y 24.58), lám. LXXVIII).

Los leones, asociados o no a imágenes antropomorfas, están bien representados en la orfebrería y en la toréutica de época orientalizante del suroeste peninsular. Por su significación en relación con el tema que nos ocupa, destacamos entre las joyas las arracadas de oro de Marchena (Sevilla) (Fernández Gómez 1997: 66-69) que, al parecer, se adornaban con colgantes en forma de crecientes, esferas, prótomos de león "de aspecto fiero " $\mathrm{y}$ " un adorno en forma de $\mathrm{T}$ con caras humanas mirando en sentidos opuestos (...), caras serias, inexpresivas, de perfil circular (...), auténticas cabezas cortadas" (Ídem: 67), en los cuales se reconocen motivos simbólicos de naturaleza religiosa, como el creciente, que se vincula a divinidades femeninas de la fecundidad (Ídem: 68). Del mismo conjunto, fechado de forma aproximada entre mediados y fines del siglo VI a.C., formaba parte una cadeneta, "como si fuera un collar o gargantilla, y rematada en un disco con la representación troquelada de una cabeza de animal, sólo su cara, que podría identificarse con la de un león (...)" (Ídem: 66).

"Cabezas cortadas" se han visto también en las placas áureas extremeñas de La Martela y de Serradilla, en el primer caso asociadas asimismo a prótomos zoomorfos que Berrocal (1989: 281, 285 y 287, figs. 1 y 2) considera équidos o cánidos, aunque es más corriente suponerlos felinos. El autor (Ídem: 287) descubre en estas representaciones cultos y creencias célticas (en contra, Blanco y Celestino 1998: 75), pero estos rostros, semejantes a los figurados en un anillo de La Aliseda (Blázquez 1975: 134, lám. 49A), conocidos también en otros ámbitos de la joyería orientalizante peninsular (Perea 1991: 187), podrían ser representaciones de carácter apotropaico alusivas a una divinidad, como lo son "las máscaras de Hathor" (Bonnet 1996: 20) que documentamos en algunos "braseros" de bronce o en pendientes de Sines (Portugal) (Nicolini 1990: 312-313 y lám. 54,d) y de Cádiz (Perea 1991: 180) en los cuales la imagen antropomorfa se asocia a otros símbolos de reconocida significación religiosa. El mismo valor cabe atribuir a las caras humanas femeninas que rematan la parte inferior del asa en los jarros de bronce hallados en el castro de Las Cogotas (Ávila) y en una necrópolis ibérica de Benalúa (Granada), ambos de fechas posteriores a fines del siglo VI (Celestino 1991: 71-73 y fig. 9). En el primero, la cabeza humana se funde en la composición con una flor de loto invertida; alojada en su interior, los extremos de los bucles y el mentón de la figura semejan los bordes de los pétalos florales. En la pieza granadina, una cabeza felina se aplicó sobre la frente de un rostro que podría considerarse una auténtica "cabeza cortada" a no ser por sus orejas puntiagudas de naturaleza animal, similares, por otra parte, a las que posee la que se supone representación de Tanit grabada en un betilo fechado en el siglo V a.C. (Fantar 1997: I, 1183 y II, 8249). 
Prótomos de león con fauces abiertas y bustos antropomorfos formaban los ángulos del lecho de El Torrejón de Abajo (Cáceres), que aunque fechado en el s. VII a.C., se amortizó en una tumba más tardía (Jiménez Ávila 1998: 86 y 90) (Fig. 12). La identificación como garras, y no como antebrazos, de las protuberancias representadas esquemáticamente en el busto de las figuras humanas, ha hecho que se interpreten como esfinges - con o sin alas, femeninas (De Alvarado y Aranegui 2000: 274) o masculinas (Jiménez Ávila 1998: 82)- las que para otros autores (García-Hoz 1991: 468) podrían ser imágenes de Astarté. La reconstrucción de esta pieza ha permitido descubrir la funcionalidad de otras semejantes halladas en estado más fragmentario e incompleto, la mayor parte rematadas por cabezas leoninas (Jiménez Ávila 1998: 90-91). En el Próximo Oriente, principalmente en ámbito sirio y a partir del siglo IX a.C., documentamos imágenes de leones flanqueando los lechos de aparato. Se tienen por representaciones apotropaicas, en calidad de animales guardianes, expresivas, a su vez, de esferas de poder, a menudo relacionadas con la realeza (Keel y Uehlinger 2001: 190), como es el caso también de la cama de que tratamos y de las que, con o sin elementos zoomorfos, se han hallado en sepulturas chipriotas y etruscas (Jiménez Ávila 1998: 80-82 y 90).

La misma función protectora podrían tener las esfinges, si lo fueran, porque pensamos que no debería desestimarse totalmente la propuesta que ve en los prótomos antropomorfos del lecho de El Torrejón de Abajo la representación de la omnipresente diosa patrona de la colonización fenicia en Occidente. Keel y Uehlinger (2001: 192) llegan a la conclusión de que a partir de la fase II B de la Edad del Hierro próximooriental (925-720/700 a.C.), las representaciones de leones rugientes se desvinculan de las divinidades femeninas a las que el animal se asociaba siempre, como símbolo o atributo, en etapas anteriores. El lecho de Assurbanipal, obra de artesanos sirios que conocemos a través de un relieve del palacio de Nínive, se decora, además de con leones, con una imagen de "mujer asomada a la ventana" que puede corresponder a una divinidad (Ídem: 202), pero éste y otros ejemplos sólo indicarían para los autores "que las representaciones de leones sobre imágenes protectoras debían considerarse particularmente eficaces" (Ídem: 190).

Menos reparos ha planteado la identificación como imagen divina de la cabeza femenina que, flanqueada por sendos leones yacentes, remata el asa del jarro de bronce de Valdegamas (Don Benito, Badajoz) (Fig. 13). Después de que A. Blanco (1953) lo publicara por primera vez, sus características formales y estilísticas, que hacen de él una pieza única entre los vasos metálicos de época orientalizante hallados en la Península Ibérica, han sido comentadas en distintos trabajos (entre otros, García y Bellido 1964; Blázquez 1975: 77-81; Almagro-Gorbea 1977: 240; Aldana 1981; Celestino 1991), por lo cual consideramos innecesario insistir sobre estos aspectos. Lo encontró un campesino entre los restos de un edificio con varias habitaciones que se interpretó como una casa perteneciente a un poblado emplazado sobre una pequeña meseta junto al río Guadalmez (Blanco 1953: 235). Posteriormente se ha sugerido que podría tratarse de una sepultura, por ser éste el contexto de los jarros de bronce de procedencia conocida y por las aparentes analogías que dichas construcciones tienen con las que se mencionan en las noticias sobre el hallazgo del tesoro de La Aliseda, que se suponen asimismo funerarias (Almagro-Gorbea 1977: 240). Si bien estas referencias son demasiado imprecisas; el complejo funerario de El Torrejón de Abajo, al margen de cómo se articulen las diferentes estructuras que lo componen (García-Hoz y Álvarez Rojas 1992; cf. Jiménez Ávila 1998: 69-70), es un ejemplo a tener en cuenta a la hora de sopesar la verosimilitud de dicha hipótesis.

La mezcla de rasgos estilísticos, griegos, etruscos y fenicios, dificulta la adscripción de la obra a un centro de fabricación concreto, pero son más los que siguiendo la primera opinión de Blanco (1953: 240) lo consideran producto de taller etrusco ${ }^{21}$, importado en fechas de la segunda mitad del siglo VI a.C. (cf. Almagro-Gorbea 1977: 240 y De Madaria 2000: 270). En Etruria encontramos, en efecto, aparte de formas

21. Posteriormente, el mismo autor (Blanco 1963: 64) se inclinó por considerarlo como imitación de un modelo itálico hecha en taller peninsular, colonial o indígena. Blázquez (1975: 80) sitúa su fabricación en el sur de lá Península y señala en la pieza, además de las etruscas, influencias fenicias. 
semejantes, tanto en metal como en cerámica (cf. Olmos 1992: 54, nota 105), el mismo motivo de dos leones echados sobre el borde, a ambos lados de una cabeza femenina que remata el extremo superior del asa, pero estos jarros itálicos se fechan a lo largo del siglo V a.C. (Brown 1960: 128-130). Algunos rasgos morfológicos -boca, cuello y pie-, emparentan el vaso de Valdegamas con los ejemplares de asa alta y discos o rodetes sobre el borde (Celestino 1991: 78), pero también encontramos semejanzas en la decoración que estos últimos presentan. Bien conocidos en el Mediterráneo en el siglo VI a.C. (Aldana 1981: 124), se atribuyen estos jarros a fábrica rodia, unos, y a talleres etruscos, otros. A veces, como en los ejemplares peninsulares de la provincia de Granada (García y Bellido 1964: fig. 11) y de la tumba 5 de La Joya (Garrido 1970: figs. 12 y 13), presentan en el interior de la boca, bajo el extremo del asa, una flor de loto sobre palmeta. En uno de los vasos con asas de este tipo hallados en las necrópolis de Cartago, encontramos flor y capullos de loto sobre una cabeza femenina de rasgos egiptizantes, motivo este último que documentamos también en otras piezas cartaginesas estudiadas por W. Culican (1981) en las que el busto femenino, entre pequeños rodetes, constituye un elemento suelto inserto en el extremo superior del asa. La imagen, que mira hacia el interior del recipiente, luce pectoral ricamente adornado o, sólo en un caso, presenta el tronco desnudo con los pechos señalados (Cintas 1976: lám. LXXI, 1 y 3-5). Conocidos por este detalle como "jarros de égida" por sus paralelos en Egipto ${ }^{22}$, se suponen de tradición fenicia antigua, adaptada en el ámbito cartaginés a partir del siglo IV, y posiblemente antes, a vasos de formas greco-itálicas (Culican 1981: 172 y 175).

El uso de todos ellos como recipientes para vino o para agua en rituales funerarios de libación (cf. Padró 1993: 402) o de ablución (Ruiz Arbulo 1996), guarda relación posiblemente con el significado de las representaciones florales, humanas o felinas, a veces formando pequeños grupos escultóricos compuestos, que los decoran. Indicábamos más atrás que se acepta de forma prácticamente unánime que la mujer entre leones del jarro de Valdegamas puede ser una diosa representada como "Señora de los animales" (Blanco 1953: 238 y Olmos 1992: 54), una diosa propiciadora también de la fecundidad (Blázquez 1975: 80; cf. Cornelius 1989: 62), que se asoma desde el borde al interior del vaso; cuestión diferente es identificar la personalidad divina que se rodea de tales rasgos y atributos.

Como se ha visto en páginas anteriores, la iconografía de la "Señora de los leones" se conoce bien en Fenicia y en el Norte de Siria durante el I Milenio a.C., también con anterioridad, pero el mejor ejemplo, aunque no es frecuente en esta zona, lo encontramos en Palestina. Uno de los soportes cultuales cerámicos hallados en Taanach, que se fecha en el siglo $\mathrm{X}$ a.C., tiene representaciones en relieve separadas en varios registros superpuestos. En el inferior, una figura femenina desnuda, de frente y de pie, tiende los brazos hacia sendos leones de fauces abiertas cuyo cuerpo se prolonga en los laterales de la pieza. En el registro superior, un caballo pasante, animal relacionado con Anat y Astarté ${ }^{23}$, representaría, según Keel y Uehlinger (2001: 160-163), a la diosa, aunque existen otras interpretaciones (cf. Mettinger 1995: 163-166).

La figura de Astarté se impone sobre las restantes divinidades femeninas en el panteón semita del I milenio y los fenicios implantaron su culto en Occidente. Del Carambolo (Sevilla) procede la única imagen segura de esta deidad, desnuda y con peinado egipcio, entronizada, pero creemos reconocerla también bajo otras apariencias e, incluso, en ausencia de imagen antropomorfa, la identificamos a través de sus atributos simbólicos. La iconografía más frecuente durante el Período Orientalizante Tartésico es la que representa a la diosa con rasgos hathóricos ${ }^{24}$. Precisamente se aplicaron máscaras hathóricas en algunos "braseros", las jofainas metálicas que aparecen junto con los jarros en las sepulturas aristocráticas; reproducen el rostro de la divinidad cuya protección se solicita (Bonnet 1996: 21). Vino y agua están presentes en los cultos que se dedican tanto a Astarté como a Hathor. En Biblos tenía lugar una fiesta del vino en honor de la Baalat

22. Cf. Bonnet 2000 : “Ägis”, 8-9.

23. Sobre la estrecha relación de ambas divinidades, cf., entre otros: Leclant 1960: 2, nota 4; Wyatt 1984: 329.

24. La asimilación de Astarté y Hathor, entre otros, en Bonnet 1996: 20-21. 
Gubal, un epíteto que comparten asimismo ambas divinidades (cf. Scandone Matthiae 1991; Bonnet 1996: 19-22). En los cultos egipcios de Hathor, las libaciones de vino aplacaban la ira de la divinidad (Hornung 1999: 190 y Scandone Matthiae 1993: 51), pero también se le dedicaban ritos lustrales (Daumas 1977: 1026). El agua, elemento esencial para la vida, es símbolo de renacimiento (cf. Clerc y otros 1976: 233246; Ruiz de Arbulo 1996: 194-195 y nota 10), así que con una u otra finalidad, o con ambas, se honraba con estos cultos a una divinidad con prerrogativas para quitar y devolver la vida, un simbolismo que cobraría pleno sentido en el ámbito funerario. La mención de Isis, con la que se asimilan Astarté y Hathor, en los jeroglíficos grabados en el jarro de La Aliseda, confirma este supuesto (Padró 1995: 43 y 200-201). En el caso del de Valdegamas, la presencia de los leones junto a la divinidad que preside los rituales que se le dedican, podría tener también una importante carga simbólica derivada del poder de regeneración y de vida que el propio animal representa (Keel y Uehlinger 1998: 26)). La identidad de la divinidad en cuestión seguramente era cambiante, dependiendo de cada contexto cultural, pero no podemos descartar una representación de Astarté en esta "Señora de los leones".

Precisamente la asimilación que se produjo entre Astarté y Hathor, tanto en Fenicia como en Egipto, y la naturaleza leonina que ambas comparten con otras divinidades de uno y otro ámbito cultural, nos anima a proponer una lectura iconográfica, sin duda arriesgada, del jarro de boca zoomorfa propiedad del Museo Lázaro Galdiano (Fig. 14). Estudiado por A. Blanco (1953:243-244 y 1956: 10-11) de forma escueta, García y Bellido lo excluyó de las recopilaciones que dedicó posteriormente a los jarros orientalizantes, según su propia justificación (García y Bellido 1960: 55), por desconocer su procedencia y por las diferencias que presentaba con el resto de los ejemplares documentados hasta entonces. Poco más tarde, después de haber estudiado el vaso con cabeza de ciervo hallado en Mérida, el autor dedicó al jarro "Lázaro" un trabajo, que sigue siendo fundamental (García y Bellido 1964: 66-80), en el cual se describe y estudia la pieza con detalle. Con posterioridad, ha sido tratado por distintos autores (entre otros, Grau-Zimmermann 1978: 197-199 y 217).

Varios rasgos hacen de éste un ejemplar único hoy por hoy en el repertorio de jarros metálicos peninsulares. A su boca en forma de prótomo leonino, de aspecto poco fiero a pesar de que tiene fauces abiertas y lengua colgante, se añade la hechura totalmente original del cuerpo, tanto en lo que se refiere a la forma como a la decoración grabada sobre la superficie. Como es normal, un baquetón divide el recipiente en dos partes, pero, en este caso, la mitad superior no es un tronco de cono de líneas rectas, sino cóncavas; por otra parte, en el tercio próximo a la boca las paredes discurren paralelas, dotando así al vaso de un cuello esbelto y estrecho del que carecen los restantes ejemplares conocidos, con lo cual se consigue un cuerpo de silueta más grácil. La cabeza del animal, cuya expresión debía resaltar un pequeño disco de otro material alojado en los huecos que ahora presentan los ojos, está delimitada por una línea en suave relieve contorneada por una banda estrecha rellena de líneas transversales. Por detrás y a ambos lados de la cabeza, se grabaron dos bandas estrechas cruzadas, rellenas de líneas o puntos Por debajo, sobre el cuello de la vasija, que es también la garganta del felino, se desarrollan tres bandas yuxtapuestas y paralelas, rellenas la superior e inferior de líneas finas verticales y la del medio con una línea de puntos en horizontal. Del borde inferior de esta cenefa pende una guirnalda que alterna, en posición invertida, flores de cinco pétalos y capullos de loto, algunos de aspecto más ictiomorfo que floral (Fig. 14:2). La decoración se completa con una franja de triángulos contiguos, con el vértice hacia abajo y rellenos de líneas irregulares, que rodea la mitad globular del vaso, inmediatamente bajo el baquetón. Dos líneas paralelas delimitan el motivo por la parte inferior; conforman los bordes de una estrecha banda en la que se distribuyen grupos de trazos verticales, espaciados con regularidad. Debemos señalar, por último, que este vaso es también el único que presenta una sola cabeza de serpiente en el extremo superior del asa. 
Para Blanco (1956: 11) y García y Bellido (1964: 70,74) la pieza se habría fabricado en un taller peninsular entre la segunda mitad o fines del siglo VII y principios del VI a.C. ${ }^{25}$, pero dado que se han encontrado en Etruria ejemplares cerámicos con boca leonina, se ha propuesto el mismo origen itálico para el jarro "Lázaro" (Aldana 1981: 123). El más interesante de los hallazgos etrus $\cos ^{26}$ es el vaso de Bruselas (Fig. 15) en el que se unen el cuerpo piriforme y una decoración figurada de carácter alegórico en estilo etrusco orientalizante (Brown 1960: 38, lám. XVIII). Los dos son muy similares, pero eso no garantiza una procedencia común (cf. Grau-Zimmermann 1978: 198). La forma de los jarros zoomorfos etruscos es fenicia y en el Próximo Oriente había una larga tradición de recipientes con forma de cabeza de animal, leones, carneros u otros ${ }^{27}$, que debieron mantener los artesanos fenicios en las colonias de ultramar (cf. Gubel 1985: 200).

En el ámbito de la religión fenicia encontramos también los testimonios arqueológicos que nos permiten sugerir que la cabeza felina del vaso del Museo Lázaro Galdiano, leona más que león en nuestra opinión, podría ser una imagen leontocéfala de la diosa Astarté.

Por una parte, conocemos probables representaciones de la diosa en vasos plásticos. Frascos con forma de mujer, sola o con niño, o de cabeza femenina, fabricados en alabastro, fayenza o cerámica, se conocen en el Próximo Oriente, Rodas, Chipre, Egipto, Grecia o Etruria, en fechas dispares comprendidas en el II y I milenios a.C. Todos ellos se suponen expresiones de ideas religiosas relacionadas con la vida y el renacimiento (Clerc y otros 1976: 183-290) ${ }^{28}$. Muchos de los hallazgos se asocian a templos dedicados a divinidades femeninas, diferentes según los sitios, que estarían representadas, o al menos, aludidas por sus competencias, en los propios vasos. En la iconografía de mujer desnuda con vientre abultado y pechos caídos, que presentan algunos ejemplares de alabastro, se ha visto la imagen de una diosa madre, "dispensadora de vida y leche" (Buchholz 1999: 639-640 y figs. 105 a-c). La misma idea ${ }^{29}$ expresa la figura femenina entronizada, un exclusivo vaso plástico de alabastro de procedencia oriental, amortizado en una tumba ibérica de Galera, en la cual reconocemos a la diosa Astarté ${ }^{30}$. Otros vasos antropomorfos son alabastrones de cuerpo alargado y boca en forma de busto de mujer que sostiene en las manos un pájaro o una flor (cf. Riis 1956). Al margen de su posible relación con el mundo de la maternidad, que aquí se muestra menos evidente, nos interesa destacar que estos frascos para perfumes, cuya producción se concentra en la isla de Rodas durante el siglo VII a.C., se han relacionado asimismo con la diosa semita. Un conocido vaso egipcio de alabastro reproduce el busto y el rostro de la diosa Hathor, cuyas relaciones con Astarté son bien conocidas (Bonnet 1996: 20-22 y 63) ${ }^{31}$. La cabeza de la diosa egipcia, se representa también a veces en las cantimploras de Año Nuevo, envases para la fecundante y vivificadora agua del Nilo, "agua de juventud", que se supone que pudieron contener también los vasos antropomorfos. Una de estas cantimploras, que se difundieron por todo el Mediterráneo, se ha encontrado en una tumba de cremación de la necrópolis de época Orientalizante de Villajoyosa (Alicante), recientemente excavada. La pieza se fecha hacia el 600 y presenta sendas cartelas

25. García y Bellido (1964: 79) se inclinó por fechas de la segunda mitad del VII, pero tampoco descartó (Ídem: 70) la del siglo VI que proponía Brown (1960: 39), que es la que aceptan hoy otros autores (entre otros, Blázquez 1975: 71).

26. Aldana (1981: 123) alude a un ejemplar etrusco decorado en el cuello con una banda de flores y capullos de loto, que no se cita en otros trabajos (cf. Brown 1960: 37-39 y Gran Aymerich 1983: 81 y nota 14)

27. En un ejemplar con cabeza de león se grabó una inscripción que prueba la función votiva de estas piezas: "Rostro de león que Naran ha ofrecido a Reshep-gan” (Zevulum 1987: 96-97, fig. 9). Véase también Brown 1960: 13 y lám. LXI e.

28. De este documentado trabajo, que no volvemos a citar para evitar reiteraciones, hemos extraído la información que sigue sobre los vasos antropomorfos, salvo que se indique expresamente otra fuente.

29. Olmos, Tortosa e Iguácel $(1992: 72,1)$ piensan que su función estaría relacionada con la ofrenda de perfumes.

30. No compartimos la identificación de la imagen con Tanit que propone López Grande (1999: 483).

31. La evocación del pecho (Clerc y otros 1976:235), asociado a la representación de un rostro femenino, la encontramos también en un "vaso biberón" de una tumba de Cartago (siglos IV-III a.C.). A ambos lados de la cara se pintaron una rama y un "signo de Tanit" (Cherif 1987: 141-142 $\left(n^{\circ} 5\right.$ ). La pieza es un ejemplo de las producciones más populares, más modestas, de estos recipientes antropomorfos con imágenes divinas, como muchos de los "vasos de Bes", cuya función simbólica no parece muy diferente (cf. Blakely y Horton 1986). 
laterales con inscripciones jeroglíficas que auguran a su poseedor "salud y vida eterna" (García Gandía sin fecha: 40 ).

Por otra parte, en Egipto, donde el culto de Astarté y de otras divinidades semitas se introdujo desde principios de la XVIII dinastía (Stadelmann 1967:96-111; Leclant 1975), la diosa fenicia tiene una personalidad muy rica, con rasgos contradictorios (Bonnet 1996: 67), como las egipcias Hathor y Sekhmet con las que se asimila (entre otros, Bonnet 1996: 20-22 y 65; Scandone Matthiae 1993: 14; Stadelmann 1967: 142). Tan compleja naturaleza se traduce en múltiples epítetos y formas de representación muy variadas que aluden a algún aspecto de aquélla (cf. Hornung 1999: 107 y Leclant 1960: 5). En ese ámbito egipcio Astarté aparece como diosa guerrera (cf. Leclant 1975: 500 y nota 1; Bonnet 1996: 67), irascible y feroz, y se representa como leona con cuerpo humano que guía el carro del faraón en Edfu (Leclant 1960: 54-58 y lám. IV A y B). Esta iconografía, que se considera propia de Sekhmet (cf. Leclant 1960: 55, nota 3), fue también compartida por Hathor (Hornung 1999: 105 y 107) en cuyo ser confluían el carácter violento de aquélla y la personalidad amable de su complementaria Bastet (Bleeker 1973: 70; Daumas 1977: 1027; Scandone Matthiae 1993: 17), como se aúnan en la hembra del león la agresividad y la ternura maternal (Scandone Matthiae 1993: 12). No es improbable, como señalábamos más atrás, que sea Astarté la divinidad leontocéfala representada en escarabeos de Tharros, pero no cabe duda de que esta iconografía prosperó también fuera de Egipto y de que en el ámbito púnico norteafricano se adoptó como imagen de Tanit (Marín 1995: 836 y nota 51$)^{32}$.

En la variada iconografía religiosa próximo-oriental, como también ocurre en Egipto (cf. Hornung 1999: 105-106 y 116), con frecuencia las imágenes antropomorfas de la divinidad se substituyen por las de sus atributos simbólicos (cf. Keel y Uehlinger 2001: 137-177). No es cuestión de extendernos más sobre la relación de Astarté y los leones, pero sí queremos destacar que la imagen antropomorfa de la diosa pudo reemplazarse por la de su animal atributo para manifestar el aspecto terrorífico de su personalidad, asociado, como en Egipto, a su condición guerrera. Esa es la interpretación que hace Gubel (1985) de unas pequeñas cabezas de leona de Nimrud labradas en marfil. Las piezas, que tienen la parte posterior plana para acoplarlas a un soporte, podrían ser elementos para el adorno de los caballos de guerra sobre los cuales "simplificarían y sustituirían la imagen de la diosa desnuda y los leones, el emblema de Astarté como señora de los caballos" (Ídem: 199). En apoyo de esta interpretación cita el autor un vaso de Cartago con asa alta y rodetes, un "jarro-égida" hallado en un contexto del siglo V a.C., en el que la cabeza de Hathor-Isis-Astarté se cambió por la de una leona coronada con disco solar flanqueado por uraei (Fig. 16). La pieza se considera fenicia $\mathrm{o}$, al menos, representativa de una larga tradición fenicia en la decoración de vasos con cabezas de leona (Gubel 1985: 200-202, fig. 13; cf. Culican 1981: 173-174 y nota 28) ${ }^{33}$. Curiosamente tanto las cabecitas de marfil, como la leona del jarro y otras representadas en distintos soportes (Gubel 1985: figs. 1, 2, 6, 12 y 13), presentan un círculo señalado o una cavidad sobre la frente semejante al orificio que perfora la cabeza del jarro "Lázaro", de dimensiones poco funcionales $(5 \mathrm{~mm})$ para pensar en un uso cotidiano de la pieza, aunque se pueda llenar a través de él (Fig. 14: 3). También en los jarros etruscos encontramos ejemplos de substitución de la cabeza de mujer entre leones recostados por la de un felino (Brown 1960: 125-126, 128-19 y láms. XLV b y c y XLVI a-c) ${ }^{34}$, en tanto que en los de Granada y de la tumba 5 de La Joya (Huelva), que citábamos más arriba, flores de loto y palmeta pueden ser otras formas de evocación de la divinidad ${ }^{35}$.

32. De Tharros procede una terracota fechada hacia el II-I a.C. que tiene cuerpo humano desnudo y cabeza leonina sobre la que se insertan dos puntas de flecha de largo pedúnculo (Acquaro (coord.) 1988: $\mathrm{n}^{\circ} 556$ ), pero se da como imagen de una divinidad masculina (Acquaro 1984: 49-51, figs. 1 y 2, lám. IX; Ribichini y Xella 1994: 101-102 y fig. 31).

33. Otro ejemplo de égida leonina " probablemente Bastet con cabeza de leona coronada por disco y uraei", en Herrmann 1986: 98 ( $\mathrm{n}^{\circ} 189$ ), lám. 42. Sobre la imagen felina de Astarté en un alabastron: Gubel 1985: 199-200; recuérdense los alabastrones rodios con cabeza de la diosa que citábamos más arriba.

34. El ejemplar de la lám. XLV c es de forma semejante al de Valdegamas.

35. Algunos ejemplares de Cartago asocian palmetas o lotos a la cabeza femenina (Culican 1981: 172). 
Este sucinto repaso a la documentación arqueológica pone de manifiesto la variada y confusa iconografía de la diosa, así como los soportes tan diferentes que se utilizan para mostrar imágenes que resaltan un aspecto u otro de su enrevesada personalidad (cf. Hornung 1999: 115-117). Su imagen, con apariencia humana o animal, se asoció también a vasos de tipología y materia diversa, hallados en santuarios o en tumbas. El jarro "Lázaro" tiene un marcado aire femenino y su cuello se adorna con flores de loto invertidas (Fig. 14: 1 y 2) como las que decoran, sobre el vestido, el pecho de la mujer representada en el "Bronce Carriazo", posiblemente Astarté en su condición de "Señora de los caballos" (Leclant 1960; Gubel 1985; Blázquez 1997). En la escatología funeraria, jarros, leones y lotos tienen una fuerte carga simbólica añadida a su carácter de posibles imágenes o símbolos de la divinidad. Más atrás aludíamos a la función del jarro en rituales de libación o de purificación, pero también a la producción de vasos plásticos femeninos como recipientes para el agua de la vida (cf. Buchholz 1999: 640), el "agua de juventud" de los egipcios que garantizaba la vida eterna. El león y el loto aseguran la pureza de ese agua (Clerc y otros 1976: 240), pero, a la vez, simbolizan el poder de renacimiento y de vida (Keel y Uehlinger 1998: 26; Ben Younes 1985: 68-69). Finalmente, la serpiente posee, como el león, poderes opuestos, de destrucción y de vida (Cornelius 1989: 63 y nota 46) ${ }^{36}$, rasgos contrarios que se armonizan también en la compleja naturaleza de la diosa Astarté.

\section{BIBLIOGRAFÍA}

Abreviaturas:

ACFP: Atti Congresso Internazionale di Studi Fenici e Punici (Italiano, francés o español)

KTU: Dietrich, M.;Loretz, O. y Sanmartín, J. (1976): Die keilalfabetischen Texte aus Ugarit (AOAT 24,

1), Neukirchen-Vluyn, Neukirchener Verlag.

LÄg: Lexicon der Ägyptologie

LIMC : Lexicon Iconographicum Mythologiae Classicae

ACQUARO, E. (1984): “Tharros X. La Campagna del 1983”, Rivista Studi Fenici XII,1: 46-51.

ACQUARO, E. (Coord.) (1988): "Schede", I Fenici (Moscati, S., dir.): 678 (nº 556). Milano, Bompiani.

ALDANA, C. (1981): "Aportaciones al estudio de la Toréutica Orientalizante en la Península Ibérica", Saguntum 16: 119-135.

ALMAGRO-GORBEA, M. (1977): El Bronce Final y el Periodo Orientalizante en Extremadura. (Bibliotheca Praehistorica Hispana XIV). Madrid, CSIC.

AMIET, P. (1992): Corpus des cylindres de Ras Shamra-Ougarit II. Sceaux-cylindres en hématite et pierres diverses. Ras Shamra-Ougarit IX, Paris. Éditions Recherches sur les Civilisations.

BEN YOUNES, H. (1985): "Contribution à l'eschatologie Phénico-Punique: la fleur de lotus", REPPAL I: $63-75$.

BERROCAL, L. (1989): "Placas áureas de la Edad del Hierro en la Meseta occidental", Trabajos de Prehistoria 46: 279-291.

BLACK, J. y GREEN, A. (1992): Gods, Demons and Symbols of Ancient Mesopotamia. An Illustrated Dictionary, London, British Museum Press.

BLAKELY, J.A. y HORTON, F.L. (1986): "South Palestinian Bes Vessels of the Persian Period", Levant XVIII: $111-118$.

36. Sobre asociación de serpiente y león en unos pendientes de oro de procedencia extremeña, Nicolini 1990: 608. 
BLANCO, J.L. y CELESTINO, S. (1998): "La joyería orientalizante peninsular. Diversidad y particularidades a la luz de los últimos hallazgos", Complutum 9: 61-83.

BLANCO, A. (1953): "El vaso de Valdegamas (Don Benito, Badajoz) y otros vasos de bronce del mediodía español", Archivo Español de Arqueología XXVI: 235-244.

_ (1956): "Orientalia. Estudio de objetos fenicios y orientalizantes en la Península", Archivo Español de Arqueología XXIX: 3- 51.

(1963): "El ajuar de una tumba de Cástulo", Archivo Español de Arqueología XXXVI: 40-69.

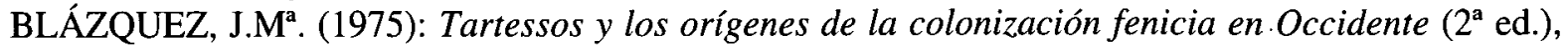
Salamanca, Universidad de Salamanca.

(1997): “Astarté, Señora de los caballos en la Hispania Prerromana”, Rivista di Studi Fenici XXV,1: 79-95.

BLEEKER, C.J. (1973): Hathor and Thoth, two key figures of the Ancient Egyptian Religion. Leiden, E.J. Brill.

BOARDMAN, J. (1984): Escarabeos de piedra procedentes de Ibiza. Museo Arqueológico Nacional, Catálogos y monografías 8, Madrid, Ministerio de Cultura.

BONNET, C. (1996): Astarté. Dossier documentaire et perspectives historiques. Roma, Istituto per la Civiltà Fenicia e Punica.

BONNET, H. (2000): Reallexikon der ägyptische Religionsgeschichte ( $3^{\mathrm{a}}$ ed.), Berlin-New York, Walter de Gruyter.

BORDREUIL, P. (1982): "Épigraphes phéniciennes inscrites sur bronze, sur pierre et sur céramique", Archéologie au Levant, Recueil R. Saïdah : 187-192. Lyon.

BOTTÉRO, J. (2001): La religión más antigua: Mesopotamia. Madrid, Ed. Trotta.

BOTTÉRO, J. y KRAMER, S.N. (1989): Lorsque les dieux faisaient l'homme. Mythologie mésopotamienne. Paris, Ed. Gallimard.

BROWN, W.LL. (1960): The Etruscan Lion. Oxford, The Clarendon Press.

BUCHHOLZ, H.G. (1999): Ugarit, Zypern und Ägäis. Kulturbeziehungen im zweiten Jahrtausend v. Chr. Münster, Ugarit-Verlag.

CAQUOT, A. y SZNYCER, M. (1980): Ugaritic Religion. Leiden, E.J. Brill.

CELESTINO, S. (1991): "Nuevos jarros tartésicos de bronce en el sur peninsular", Madrider Mitteilungen 32: 52-85.

CHERIF, Z. (1987): ““'Biberon” or Baby Feeding Bottle”, Carthage: A Mosaic of Ancient Tunisia (Ben Abed Ben Khader, A. y Soren, D. eds.): 141-142. New York, The American Museum of Natural History.

CLERC, G. y otros (1976): Fouilles de Kition II. Objets égyptiens et égyptisants: scarabées, amulettes et figurines en pâte de verre et en faïence, vase plastique en faïence. Sites I et II, 1959-1975. Nicosia, The Department of Antiquities, Cyprus.

CINTAS, P. (1976): Manuel d'Archéologie Punique II. Paris, Éd. A. et J. Picard.

CORNELIUS, I. (1989): “The Lion in the Art of the Ancient Near East: a Study of Selected Motifs", Journal of Northwest Semitic Languages XV: 53-85.

(1993): "Anat and Qudshu as the "Mistress of Animals". Aspects of the Iconography of the Canaanite Goddesses", Studi Epigrafici e Linguistici 10: 21-25.

CULICAN, W. (1981): "Phoenician Aegis Jugs", Rivista di Studi Fenici IX, 2: 169-175.

DAUMAS, F. (1977): "Hathor", $L \ddot{A} g$ (W. Helck y E. Otto, dirs.), II: 1024-1039. Wiesbaden, Otto Harrassowitz.

DE ALVARADO, M. y ARANEGUI, C. (2000): "Elementos de lecho", Argantonio rey de Tartessos (C. Aranegui, ed.): 274 ( $\left.n^{\circ} 111\right)$. Sevilla, Fundación El Monte. 
DE MADARIA, J.L. (2000): “Jarro panzudo", Argantonio rey de Tartessos (C. Aranegui, ed.): 270 (n” 106). Sevilla, Fundación El Monte.

EDWARDS, I.E.S. (1955): "A Relief of Qudshu-Astarte-Anath in the Winchester College Collection", Journal of Near Eastern Studies 14: 49-51.

FANTAR, M.H. (1997): “Tanit”, LIMC VIII,1 y 2. Düsseldorf, Artemis Verlag.

FERNÁNDEZ GÓMEZ, F. (1997): Tesoros de la Antigüedad en el Valle del Guadalquivir. Sevilla, Consejería de Cultura, CajaSur Publicaciones.

GAMER-WALLERT, I, (1978): Ägyptische und ägyptisierende Funde von der Iberischen Halbinsel, Wiesbaden, Dr. Ludwig Reichert Verlag.

GARBINI, G. (1979): "Fenici in Palestina", Annali dell'Istituto Orientali di Napoli 39:

GARCÍA ALFONSO, E. (1998): "El cilindro-sello de Vélez Málaga", Madrider Mitteilungen 39: 49-66.

GARCÍA y BELLIDO, A. (1960): "Inventario de los jarros púnico-tartésicos", Archivo Español de Arqueología XXXIII: 44-63.

- (1964): "Nuevos jarros de bronce tartessios", Archivo Español de Arqueología XXXVII: 56-80.

GARCÍA GANDÍA, J.R. (sin fecha): "Joyas, amuletos y armas. La necrópolis orientalizante de Les Casetes", Revista de Arqueología n n $^{\circ}$ 249: 36-47.

GARCÍA-HOZ ROSALES, M C. (1991): “Los bronces orientalizantes de "El Torrejón de Abajo'”, La presencia de material etrusco en la Península Ibérica (J. Remesal y O. Musso, eds.): 457-473. Barcelona, Universitat de Barcelona.

GARCÍA-HOZ ROSALES, Mª C. y ÁLVAREZ ROJAS, A. (1991): "El Torrejón de Abajo", Cáceres, I", I Jornadas de Prehistoria y Arqueología en Extremadura (1986-1990). Extremadura Arqueológica II: 199-209. Mérida-Cáceres, Consejería de Educación y Cultura de la Junta de Extremadura.

GARRIDO, J.P. (1970): Excavaciones en la necrópolis de "La Joya", Huelva (1 $1^{a}$ y $2^{a}$ Campañas). Excavaciones Arqueológicas en España 71. Madrid, Ministerio de Educación y Ciencia.

GESE, H.: (1970): "Die Religionen Altsyriens" en Gese, H.; Höfner, M. y Rudolph, K., Die Religionen Altsyriens, Altarabiens und der Mandäer: 3-232. Stuttgart, Verlag W. Kohlhammer.

GRAN AYMERICH, J.M.J.(1983): "Les céramiques phénico-puniques et le bucchero etrusque: cas concrets et considérations générales”, ACFP 1, Roma, 5-10 Novembre 1979, I: 77-87. Roma, CNR.

GRAU-ZIMMERMANN, B. (1978): "Phönikische Metallkannen in den orientalisierenden Horizonten des Mittelmeerraumes", Madrider Mitteilungen 19: 161-218.

GUARDUCCI, M. (1946-8): "Nuovi documenti del culto di Caelestis a Roma", Bull. della Commisione Archeologica di Roma 72: 21-24.

GUBEL, E. (1980): "An Essay on the Axe-bearing Astarte and her Role in a Phoenician "Triad" ", Rivista di Studi Fenici VIII, 1: 1-17.

(1985): "Phoenician Lioness Heads from Nimrud: Origin and Function", Studia Phoenicia III: Phoenicia and Its Neighbours: 181-202. Leuven, Ed. Board.

_ (1986): "Une nouvelle représentation du culte de la Gaalat Gebal?", Studia Phoenicia IV: Religio Phoenicia: 181-202. Namur. Société des études classiques.

- (2000): "Multicultural and Multimedial Aspectŝs of Early Phoenician Art, c. 1200-675 BCE", en Uehlinger, Chr. : Images as Media. Sources for the cultural history of the Near East and the Eastern Mediterranean (Ist millennium BCE), OBO 175: 185-213. Fribourg, University Press.

HELCK, W. (1971): Die Beziehung Ägyptens zu Vorderasien im 3. und 2. Jahrtausend v. Chr. Wiesbaden, Otto Harrassowitz.

HERRMANN, Chr. (1994): Ägyptische Amulette aus Palästina/Israel. Fribourg, University Press.

HERRMANN, G. (1986): Ivories from Room SW 37 Fort Shalmanaser. Commentary and Catalogue, Ivories from Nimrud (1949-1963), fasc. IV, 1. London, The British School of Archaeology. 
HÖLB, G. (1986): Ägyptische Kulturgut imphönizischen und punischen Sardinien I. (Études préliminaires aux religions orientales dans l'Empire Romain 102). Leiden, E.J. Brill.

HORNUNG, E. (1999): El Uno y los Múltiples. Concepciones egipcias de la divinidad. (Biblioteca de Ciencias Bíblicas y Orientales, 4). Madrid, Ed. Trotta.

JIMÉNEZ ÁVILA, J. (1998): "El lecho funerario de época orientalizante de "El Torrejón de Abajo" (Cáceres)", Madrider Mitteilungen 39: 67-98.

KARAGEORGHIS, V. (1969): Salamis in Cyprus: Homeric, Hellenistic and Roman. London, Thames and Hudson.

(1975): “A Gold Ornament with a Representation of an “Astarté"”, Rivista di Studi Fenici III, 1: 31-35.

KEEL, O. y UEHLINGER, CHR. (1998): Göttinnen, Götter und Gottessymbole, Freiburg, Basel, Wien, University Press.

- (2001): Dieux, déesses et figures divines. Paris, Les Éditions du Cerf.

LECLANT, J. (1960): "Astarté à cheval d'après les représentations égyptiennes", Syria XXXVII: 1-67.

(1975): "Astarte", $L \ddot{A} g$ (W. Helck y E. Otto, dirs.), I: 499- 509. Wiesbaden, Otto Harrassowitz.

LEIBOVITCH, J. (1961): “Kent et Qadech”, Syria XXXVIII: 23-34.

LEMAIRE, A. (1986): "Divinités égyptiennes dans l'onomastique phénicienne”, Religio Phoenicia. Studia Phoenicia IV (Bonnet, C.; Lipinski, E. y Marchetti, P. eds.): 87-98. Namur, Societé des Études Classiques.

LIMET, H. (1985): "La représentation du divin en Mésopotamie. Symboles et attributs", Le symbolisme dans le culte des grandes religions: Actes du colloque de Louvain-la-Neuve (octobre 1983) (Ries, J. (ed.): 95-114. Louvain-la-Neuve, Centre d'Histoire des Religions.

LIPINSKI, E. (1999): “"'Lion” and "lioness" in Northwest Semitic”, Michael. Historical, Epigraphical and Biblical Studies In Honor of Prof. Michael Heltzer (Avishur, Y. y Deutsch, R., eds.): 213-220. Tel Aviv-Jaffa, Archaeological Center Publications.

LÓPEZ GRANDE, Mª J. (1999): "Manifestaciones artísticas próximo orientales en las imágenes de los dioses de la Antigua Iberia", II Congreso de Arqueología Peninsular. Primer Milenio y metodología (De Balbín, R. y Bueno, P., eds.), II: 477-484. Alcalá de Henares, Universidad de Alcalá.

MARÍN CEBALLOS, M.C. (1995): "La diosa leontocéfala de Cartago", Arqueólogos, historiadores y filólogos. Homenaje a Fernando Gascó, vol. II. Kolaios 4: 827-843. Sevilla.

- (1998): "Presupuestos teóricos para un estudio histórico-religioso de las iconografías egipcias y egiptizantes en el mundo fenicio-púnico", Actas del Congreso "El Mediterráneo en la Antigüedad. Oriente y Occidente", Sapanu. Publicaciones en Internet II (1998) [http://www.labherm.filol.csic.es]

MARKOE, G. (1984): Phoenician Bronze Silver Bowls from Cyprus and the Mediterranean. (Classical Studies, 26). Berkeley, University of California.

MARTÍN DE LA CRUZ, J.C. (1994): "Los primeros contactos entre Grecia y la Península Ibérica. La problemática planteada por los hallazgos de Montoro (Córdoba)", Arqueología de la Magna Grecia, Sicilia y Península Ibérica (Vaquerizo, D., coord.): 111-146. Córdoba, Excma. Diputación Provincial de Córdoba.

MERLIN, A. (1910): Le sanctuaire de Baal et Tanit près de Siagu, Notes et documents publiés par la Direction des Antiquités et des Arts. Paris.

MERLO, P. (1998): La dea Asratum-Atiratu-Ašera. Un contributo alla storia della religione semitica del Nord. Roma, Pontificia Università Lateranense.

(1997): "Note critiche su alcune presunte iconographie della dea Ashera", Studi Epigrafici e Linguistici 14: 43-63.

METTINGER, T.N.D. (1995): No Graven Image?. Israelite Aniconism in Its Ancient Near Eastern Context. Stockholm, Almqvist \& Wiksell International. 
NICOLINI, G. (1990): Techniques des ors antiques. La bijouterie ibérique du VIIe. au IVe. Siècle. Paris, Picard.

OLMOS, R. (1992): "Broncística fenicia y orientalizante en el sur de la Península y en Ibiza. Una aproximación iconográfica y simbólica", Producciones artesanales fenicio-púnicas. VIJornadas de Arqueología fenicio-púnica (Ibiza 1991): 41-64. Ibiza, Consellería de Cultura, Educació i Esports.

OLMOS, R.; TORTOSA, T. e IGUÁCEL, P. (1992): "Catálogo", La sociedad ibérica a través de la imagen: 33- 167. Madrid, Ministerio de Cultura.

PADRÓ i PARCERISA, J. (1993): "Hathor dans l'Hispanie pré-romaine", Hommages à Jean Leclant, BdE 106/3: 397-404. Le Caire, Institut Français d'Archéologie Oriental.

- (1995): New Egyptian-type Documents from the Mediterranean Littoral of the Iberian Peninsula before the Roman Conquest. Montpellier, Université Paul Valéry.

PARROT, A. (1969): Sumer. Madrid, Ed. Aguilar.

PEREA, A. (1991): Orfebrería prerromana. Arqueología del oro. Madrid, Caja Madrid.

POMPONIO, F. y XELLA, P. (1997): Les dieux d'Ebla. Étude analytique des divinités éblaïtes à l'époque des archives royales du IIIe millénaire. Münster, Ugarit-Verlag.

PUECH, E. (2000): "Les pointes de flèche inscrites de la fin du Ile. millénaire en Phénicie et Canaan", ACFP 4, I: 251-269. Cádiz, Servicio de Publicaciones de la Universidad de Cádiz.

(1999): "Lioness", Dictionary of Deities and Demons in the Bible (Van der Toorn, K.; Becking, B., van der Horst, P. eds.): 524-525. Leiden-Boston-Köln, Brill.

QUILLARD, B. (1970-71): "Les étuits porte-amulettes carthaginois", Karthago XVI: 4-32.

- (1987): Bijoux Carthaginois II. Porte-amulettes, sceaux-pendentifs, pendants, boucles, anneaux et bagues. Louvain-La-Neuve, Institut Supérieur d'Archéologie et d'Histoire de l'Art.

REDISSI, T. (1990): "Les amulettes de Carthage representant les divinités leontocephales et les lions", REPPAL V: 163-216.

RIBICHINI, S. (1995): “Flebili dee fenicie", Rivista Studi Fenici XXIII, 1: 23-25.

RIBICHINI, S. y XELLA, P. (1994): La religione fenicia e punica en Italia. Roma, Librería dello Stato, Istituto Poligrafico e Zecca dello Stato.

RIIS, P.J. (1956): “Sculptured Alabastra", Acta Archaeologica XXVII: 23-33. Kobenhavn.

RÖLLIG, W. (1995): "Onomastic and Paleographic Considerations on Early Phoenician Arrow-Heads", $A C F P$ 3, I: 348-355. Tunis, Institut National du Patrimoine.

RUIZ DE ARBULO, J. (1996): "La asociación de jarras y palanganas de bronce tartesias e ibéricas. Una propuesta de interpretación", Revista Estudios Ibéricos 2: 173-199.

SCANDONE MATTHIAE, G. (1991): "Hathor Signora di Biblo e la Baalat Gebal”, ACFP 2, I: 401-406. Roma, CNR.

SCANDONE MATTHIAE, G. (1993): "L'occhio del sole. Le divinita' feline femminili dell'Egitto faraónico", SEL 10: 9-19.

STADELMANN, R. (1967): Syrisch-palästinensische Gottheiten in Ägypten. Leiden, E.J.Brill.

SYDENHAM, E.A. (1952): The Roman Republican Coinage. London, Spink \& Son.

TEISSIER, B. (1996): Egyptian Iconography on Syro-Palestinian Cylinder Seals of the Middle Bronze Age (OBO, Series Archaeologica $\left.\mathrm{n}^{\circ} 11\right)$. Fribourg, University Press.

VERCOUTTER, J. (1945): Les objets égyptiens et égyptisants du mobilier funéraire cathaginois. Paris, Lib. Orientaliste Paul Geuthner.

WIGGINS, S.A. (1991): "The Myth of Asherah: Lion Lady and Serpent Goddess", Ugarit Forschungen 23: 383-394.

WYATT, N. (1984): “The 'Anat Stela from Ugarit”, Ugarit Forschungen 16: 327-337.

ZEVULUM, U. (1987): “A Canaanite Ram-Headed Cup”, Israel Exploration Journal 37 (2-3): 88-104. 


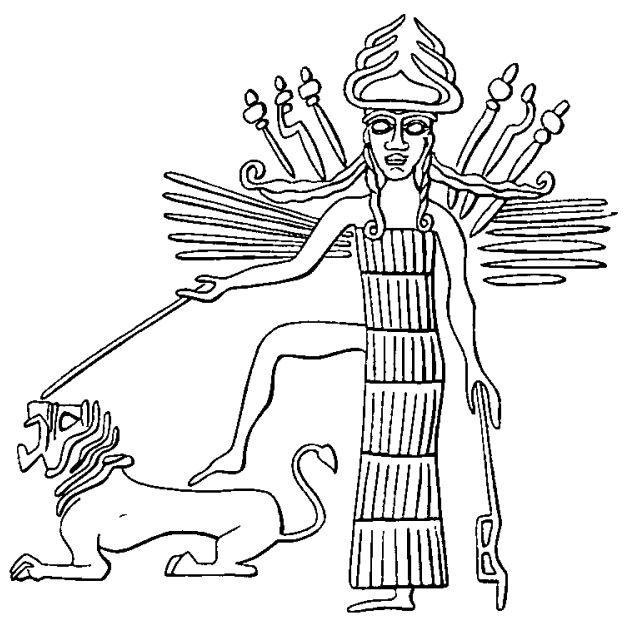

Fig. 1. La diosa Ishtar. Cilindro-sello de época neoasiria (Black y Green 1992).

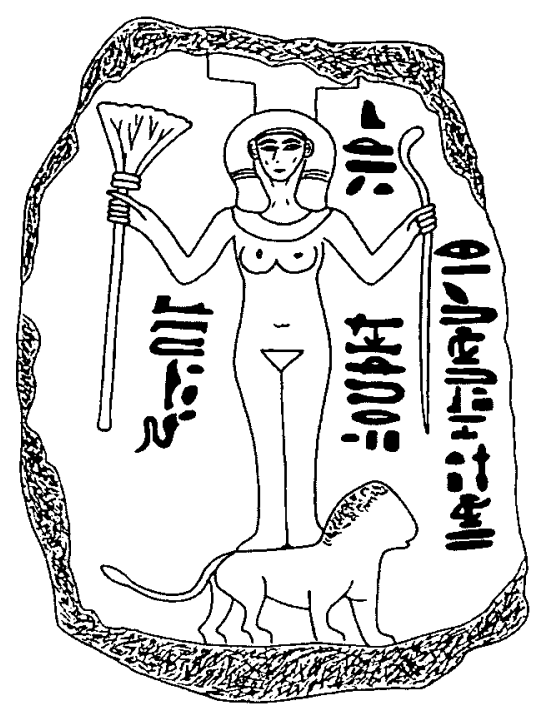

Fig. 2. Estela egipcia del Winchester College, Oxford.
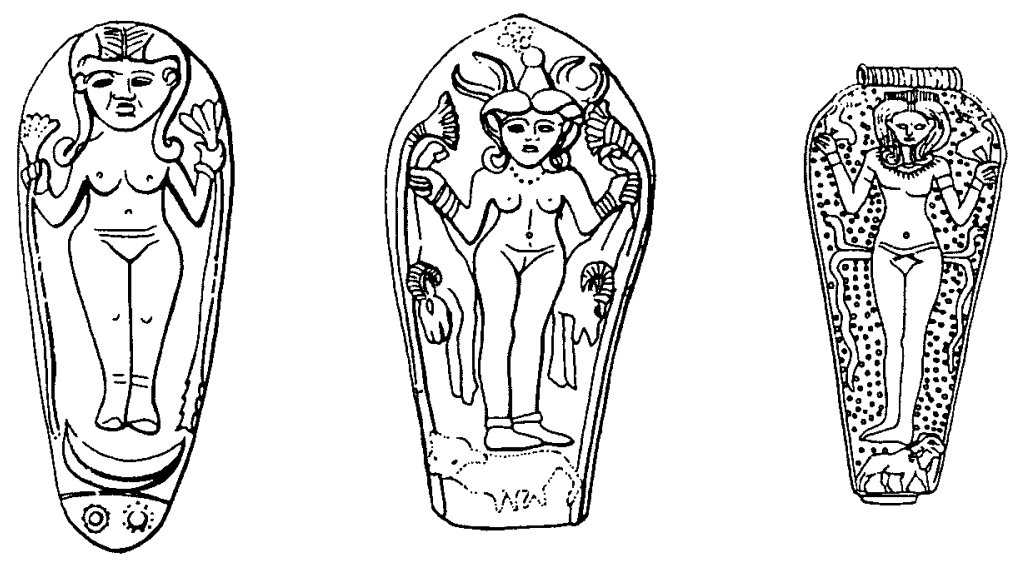

Fig. 3. Colgantes de Minet-el-Beida. 


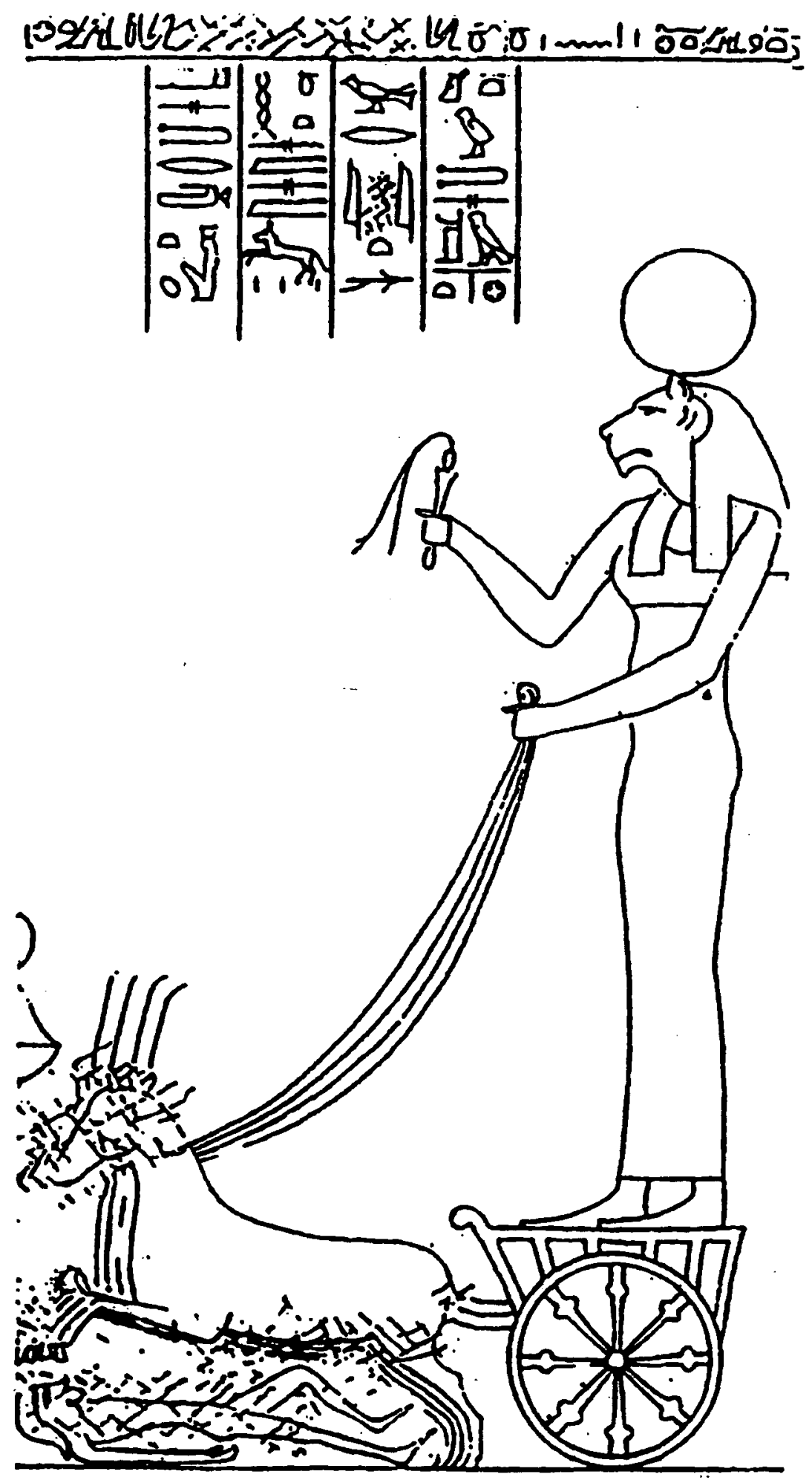

Fig. 4. Astarté leontocéfala. Relieve del templo de Edfu (Leclant 1960). 


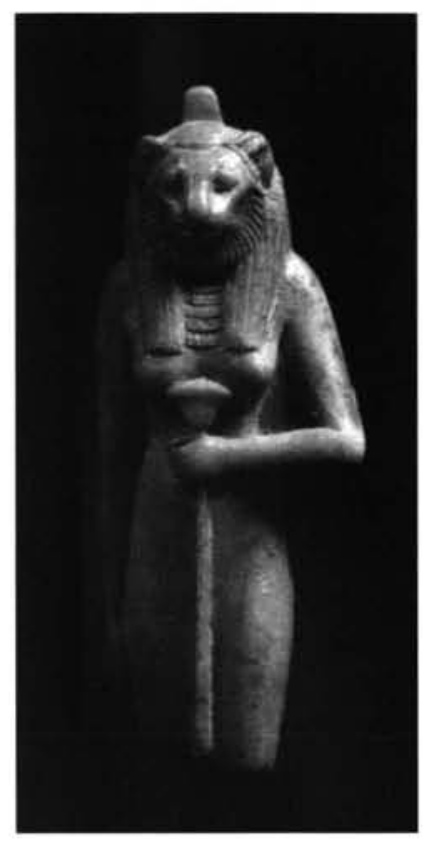

Fig. 5. Sekhmet (I Fenici 1988).
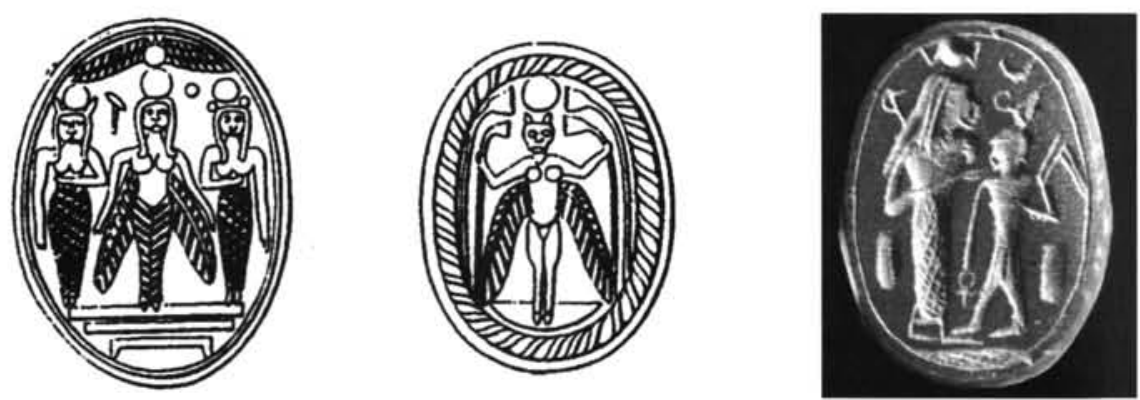

Fig. 6-8. Diosas leontocéfalas en escarabeos de Tharros (Hölb $1986\left(n^{\text {os }}\right.$. 6 y 7) e I Fenici $1988\left(n^{\circ} 8\right)$. 


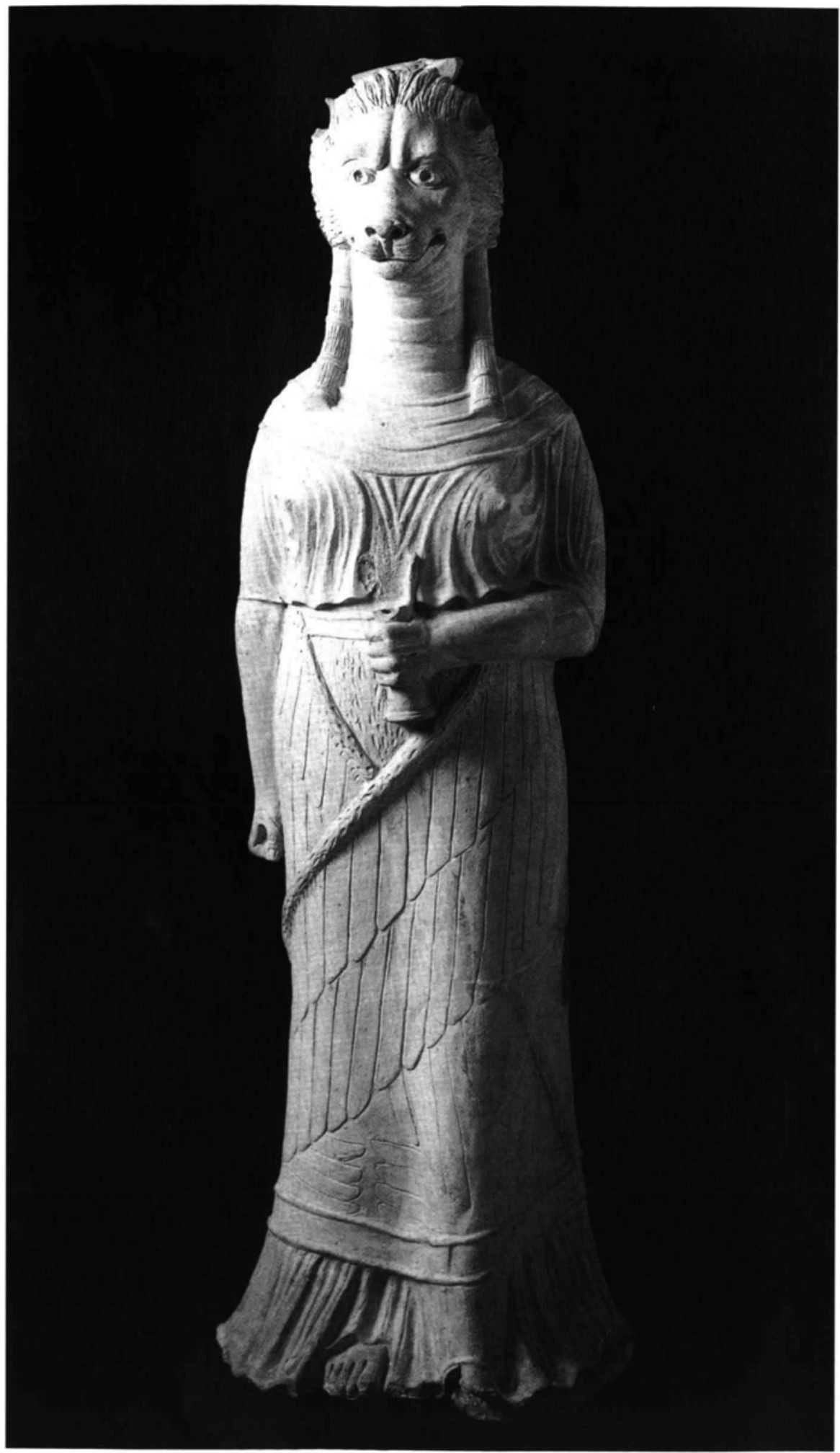

Fig. 9. Diosa leontocéfala de Thinissut (Túnez) (I Fenici 1988). 


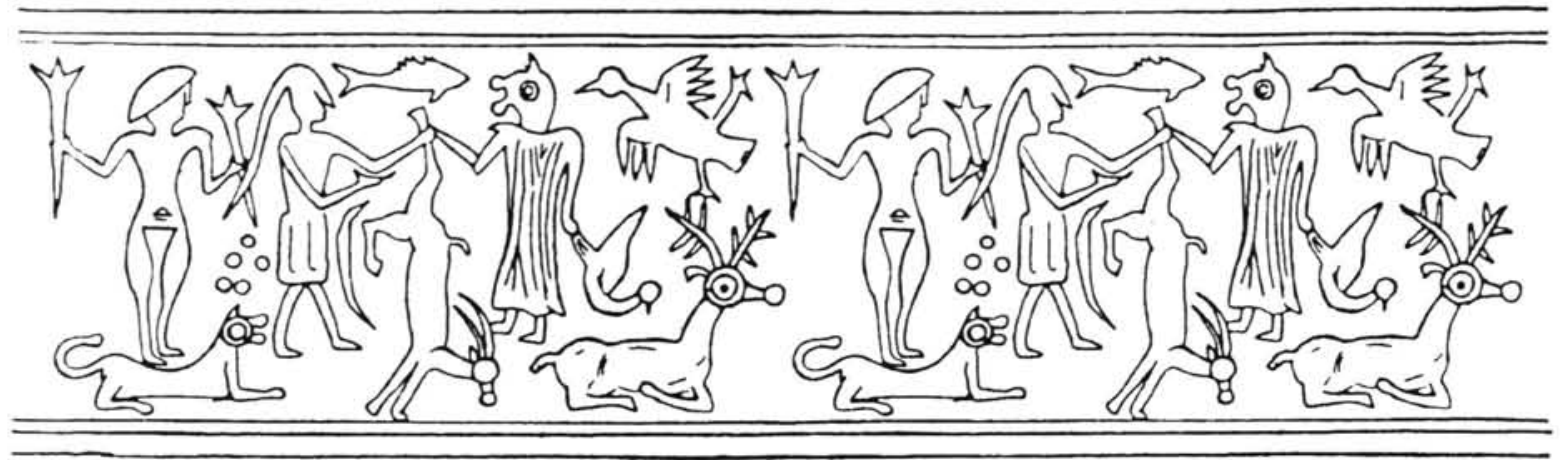

Fig. 10. Cilindro-sello de Vélez Málaga (García Alfonso 1998).

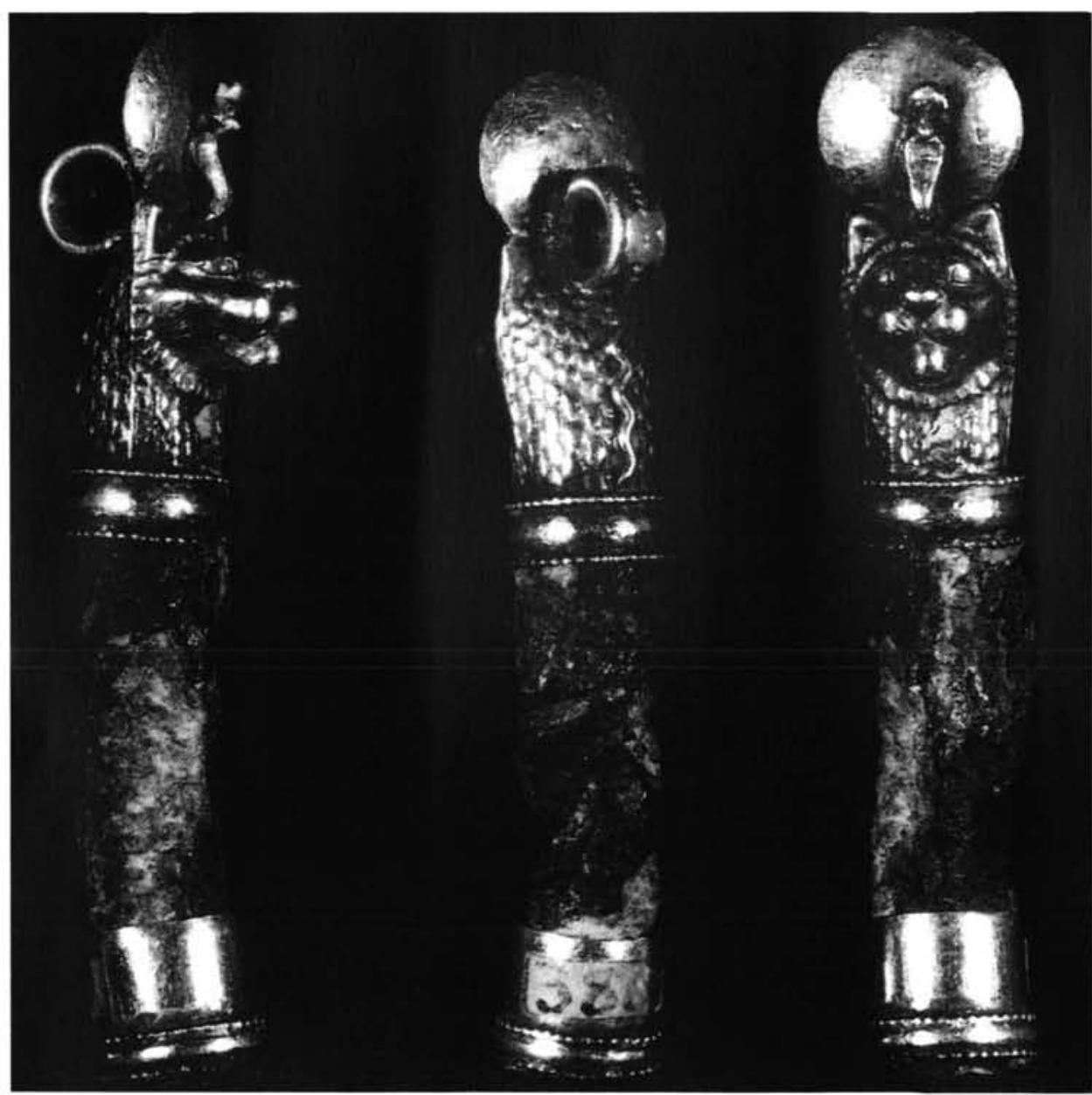

Fig. 11. Estuche porta-amuleto con prótomo de leona. Necrópolis de Cádiz (Nicolini 1990). 

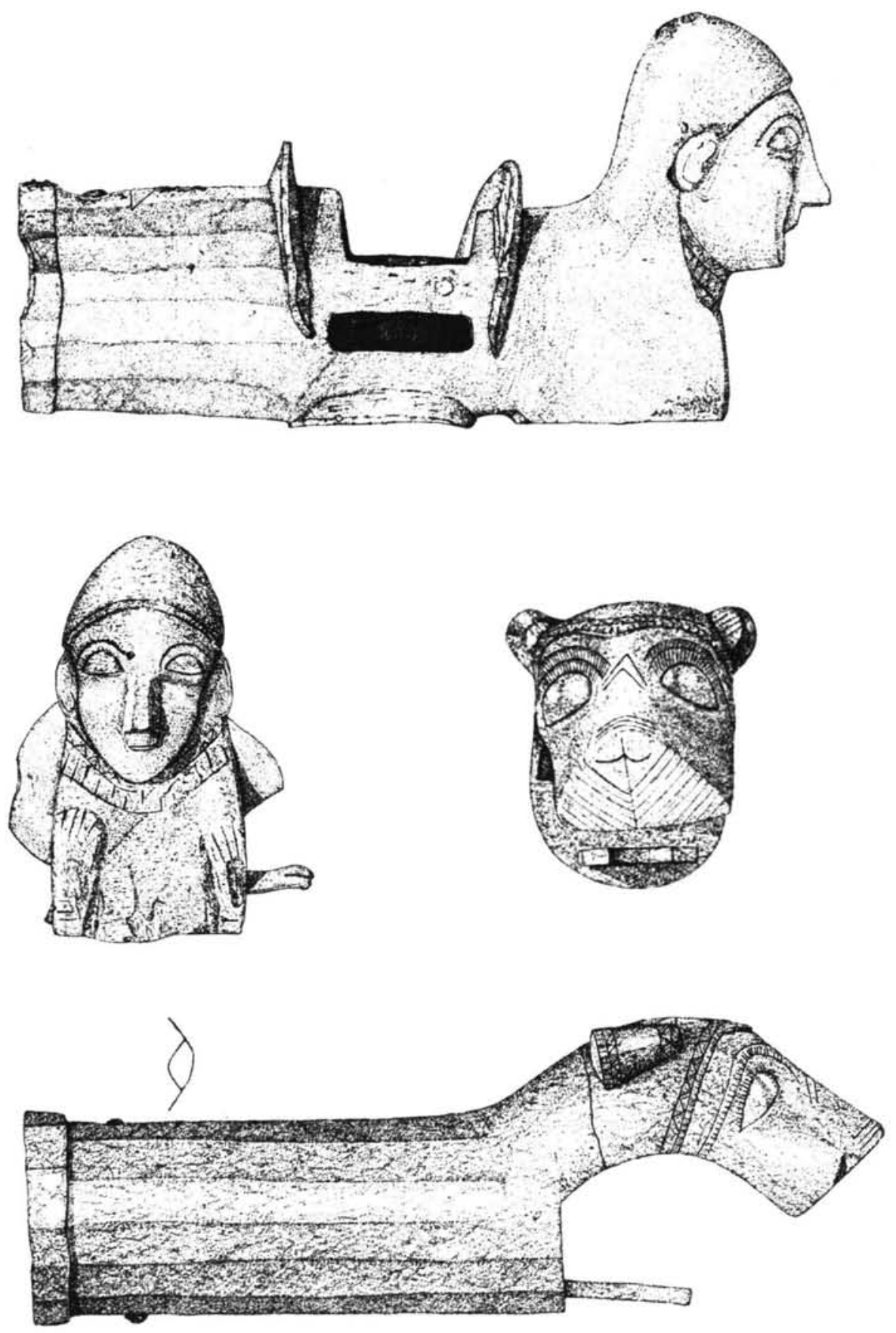

Fig. 12. Piezas del lecho de Torrejón de Abajo (Cáceres) (Jiménez Ávila 1998). 


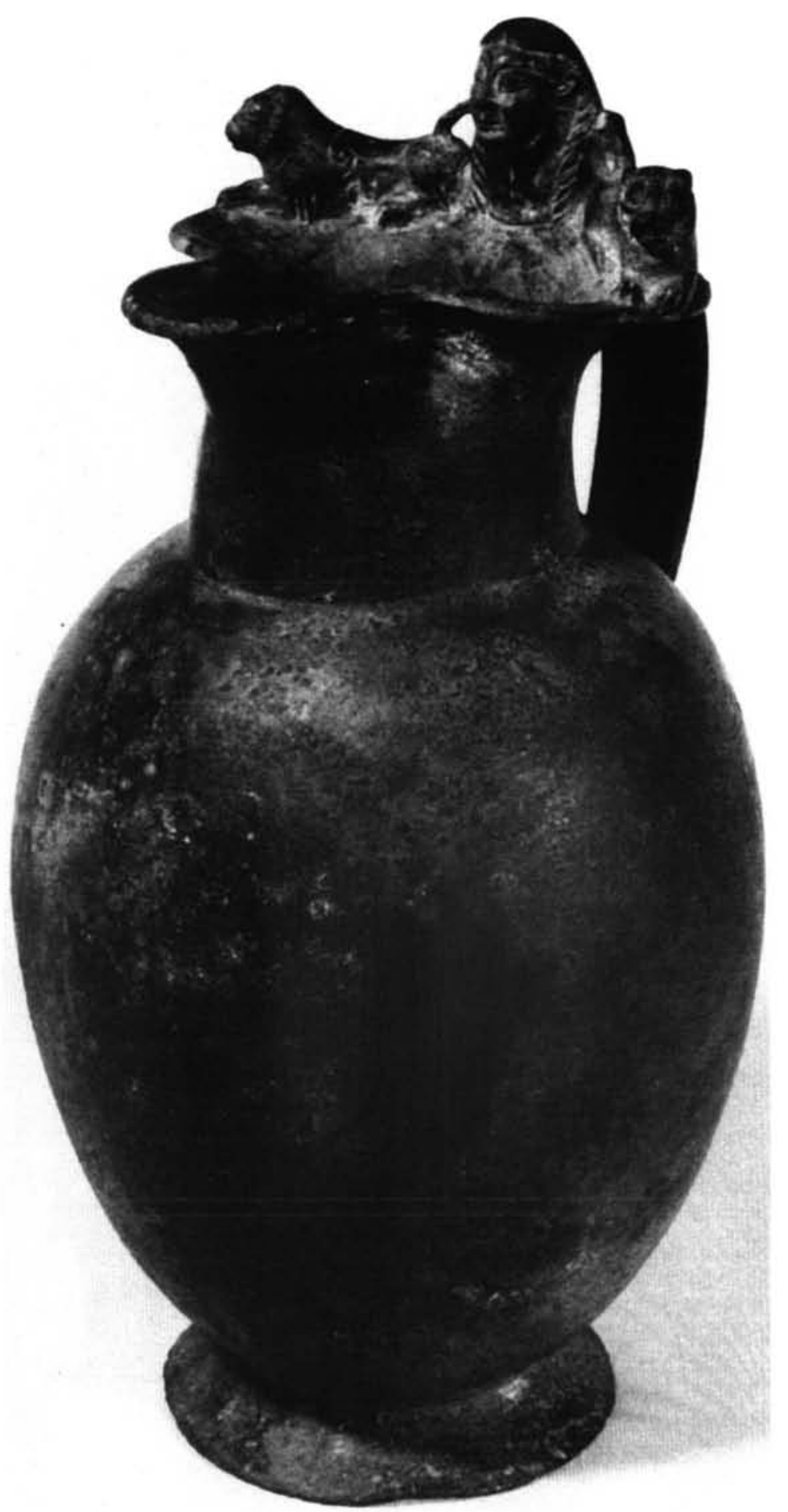

Fig. 13. Jarro de Valdegamas (Argantonio Rey de Tartessos 2000). 

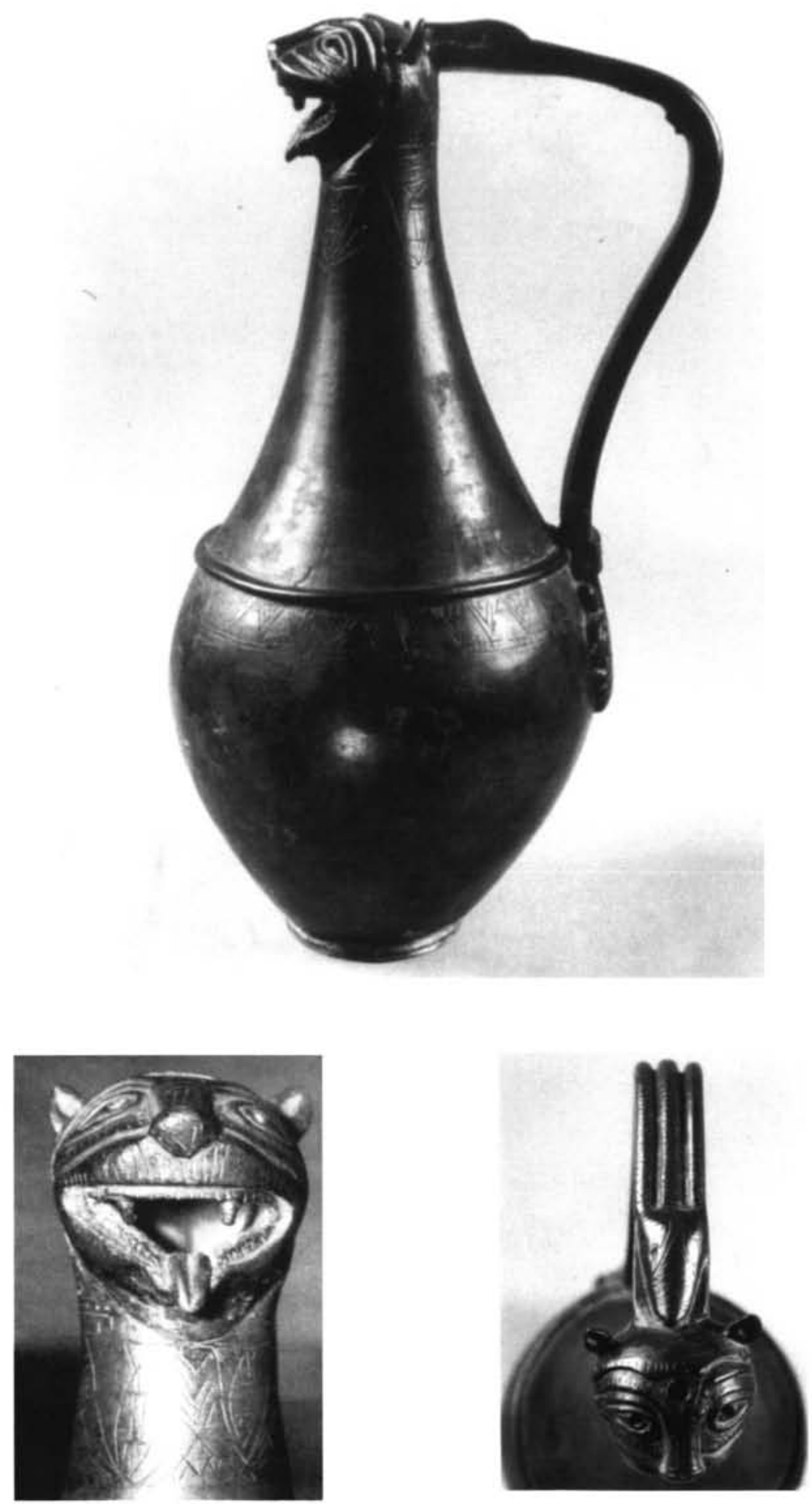

Fig. 14. Jarro del Museo Lázaro Galdiano (1 y 3: DAI-MAD-R-86-3 y R-4-88-3. Fotos Peter Witte. 2: Blázquez 1975). 


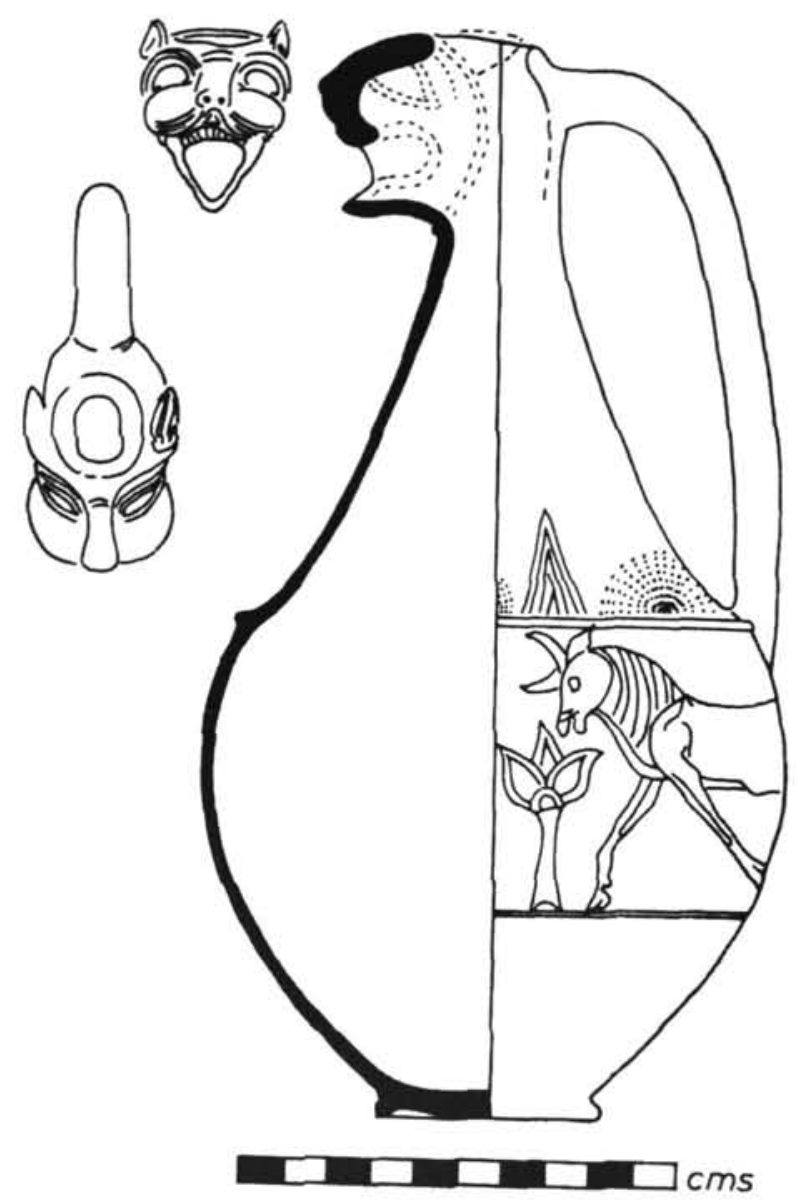

Fig. 15. Jarro etrusco, Bruselas (Gran Aymerich 1983).

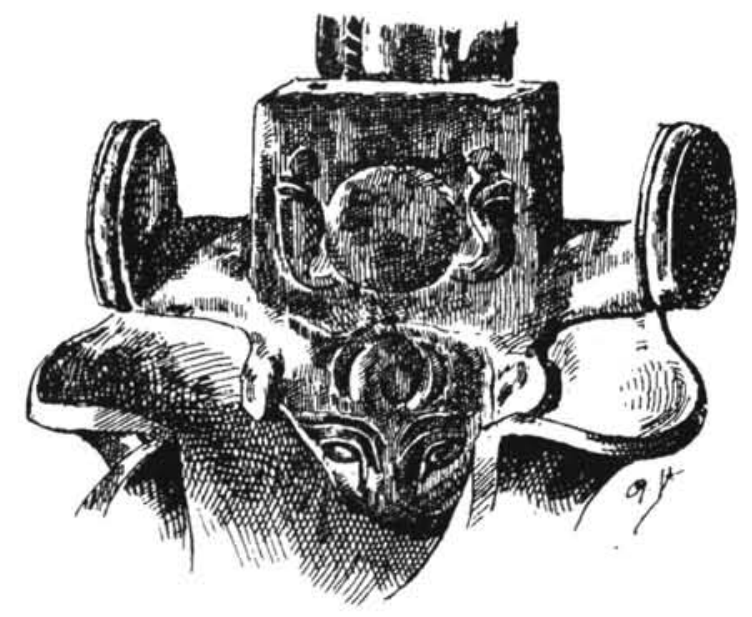

Fig. 16. Jarro de Cartago, detalle (Gubel 1985). 